\title{
Creatine Enhances Mitochondrial-Mediated Oligodendrocyte Survival After Demyelinating Injury
}

\author{
ㅈelly A. Chamberlain, ${ }^{1,2}{ }^{\circledR}$ Kristen S. Chapey, ${ }^{1}$ Sonia E. Nanescu, ${ }^{1}$ and ${ }^{\oplus}$ Jeffrey K. Huang ${ }^{1,2}$ \\ ${ }^{1}$ Department of Biology and ${ }^{2}$ Interdisciplinary Program in Neuroscience, Georgetown University, Washington, District of Columbia 20057
}

\begin{abstract}
Chronic oligodendrocyte loss, which occurs in the demyelinating disorder multiple sclerosis (MS), contributes to axonal dysfunction and neurodegeneration. Current therapies are able to reduce MS severity, but do not prevent transition into the progressive phase of the disease, which is characterized by chronic neurodegeneration. Therefore, pharmacological compounds that promote oligodendrocyte survival could be beneficial for neuroprotection in MS. Here, we investigated the role of creatine, an organic acid involved in adenosine triphosphate (ATP) buffering, in oligodendrocyte function. We found that creatine increased mitochondrial ATP production directly in oligodendrocyte lineage cell cultures and exerted robust protection on oligodendrocytes by preventing cell death in both naive and lipopolysaccharide-treated mixed glia. Moreover, lysolecithin-mediated demyelination in mice deficient in the creatine-synthesizing enzyme guanidinoacetate-methyltransferase (Gamt) did not affect oligodendrocyte precursor cell recruitment, but resulted in exacerbated apoptosis of regenerated oligodendrocytes in central nervous system (CNS) lesions. Remarkably, creatine administration into Gamt-deficient and wild-type mice with demyelinating injury reduced oligodendrocyte apoptosis, thereby increasing oligodendrocyte density and myelin basic protein staining in CNS lesions. We found that creatine did not affect the recruitment of macrophages/microglia into lesions, suggesting that creatine affects oligodendrocyte survival independently of inflammation. Together, our results demonstrate a novel function for creatine in promoting oligodendrocyte viability during CNS remyelination.
\end{abstract}

Key words: apoptosis; creatine; demyelination; guanidinoacetate-methyltransferase; oligodendrocyte; regeneration

\section{Significance Statement}

We report that creatine enhances oligodendrocyte mitochondrial function and protects against caspase-dependent oligodendrocyte apoptosis during CNS remyelination. This work has important implications for the development of therapeutic targets for diseases characterized by oligodendrocyte death, including multiple sclerosis.

\section{Introduction}

Oligodendrocytes are glial cells of the CNS that myelinate axons to promote saltatory conduction and provide neurons with energy metabolites, including lactate (Fünfschilling et al., 2012; Lee et al., 2012). Oligodendrocyte and myelin loss is a hallmark fea-

Received June 16, 2016; revised Dec. 3, 2016; accepted Dec. 28, 2016.

Author contributions: K.A.C. and J.K.H. designed research; K.A.C., K.S.C., and S.E.N. performed research; K.A.C. and J.K.H. analyzed data; K.A.C. and J.K.H. wrote the paper.

This work was supported by the National Institute of Neurological Disorders and Stroke-National Institutes of Health (Training Grant 5T32NS041218 to K.A.C.), the Howard Hughes Medical Institute (Georgetown Hughes Undergraduate Scholars Program to K.S.C.), National Multiple Sclerosis Society Pilot Research Grant (PP-1606-24509 to J.K.H.) and Georgetown University (startup funds to J.K.H.). Wethank Dr. Dirk Isbrandt (University of Cologne) for providing us with Gamt ${ }^{+/}$ mice for these experiments, Dr. Konstantina Psachoulia for training in surgical procedures, and Dr. Thomas Coate for carefully reading this manuscript.

The authors declare no competing financial interests.

Correspondence should be addressed to Jeffrey Huang, Department of Biology, Regents Hall 406, Georgetown University, $37^{\text {th }}$ and 0 St., NW, Washington, DC 20057. E-mail: jeffrey.huang@georgetown.edu.

DOI:10.1523/JNEUROSCI.1941-16.2016 Copyright $\odot 2017$ Chamberlain et al.

This is an open-access article distributed under the terms of the Creative Commons Attribution License Creative Commons Attribution 4.0 International, which permits unrestricted use, distribution and reproduction in any medium provided that the original work is properly attributed. ture of the chronic inflammatory disease multiple sclerosis (MS) (Wolswijk, 1998; Compston and Coles, 2008). Although existing MS therapies are able to reduce disease severity, they do not prevent progression into the chronic neurodegenerative phase of the disease (Rice, 2014). Myelinating oligodendrocytes regenerate spontaneously after demyelination in the early phase of MS because of the availability of endogenous oligodendrocyte precursor cells (OPCs) in the CNS (Franklin and Gallo, 2014). However, this process becomes increasingly difficult with disease progression and results in progressive axonal loss and the accumulation of clinical disability (Franklin, 2002; Haines, Inglese, and Casaccia-Bonnefil, 2009; Fitzner and Simons, 2010; Dutta and Trapp, 2011). Why remyelination ultimately fails in MS is not well understood. One possibility is that oligodendrocytes do not survive well under the inflammatory environment in MS. For example, oligodendrocytes are highly vulnerable to hypoxic-ischemic injury (Ness et al., 2001; McIver et al., 2010; Jablonska et al., 2012), a feature of MS lesions (Lassmann, 2016), and readily undergo inflammation-mediated cell death (Vartanian et al., 1995; Akassoglou et al., 1998; Baerwald and Popko, 1998). 
Previous studies have demonstrated that oligodendrocyte survival can be achieved in murine autoimmune-mediated models of demyelination by overexpressing the anti-apoptotic protein p53 (Hisahara et al., 2000), by enhancing the integrated stress response (Lin et al., 2007; Way et al., 2015), or by deleting FADD (Mc Guire et al., 2010), a receptor adaptor protein involved in apoptotic initiation. Moreover, mice with enhanced oligodendrocyte survival also displayed reduced disease severity. These studies suggest that enhancing oligodendrocyte survival would be beneficial as a treatment strategy in MS.

One candidate for promoting oligodendrocyte survival is creatine, a cytoprotective organic acid (Matthews et al., 1998, 1999; Klivenyi et al., 1999; Andres et al., 2005) that has been shown to regulate neuronal mitochondrial activity (Lee and Peng, 2008) and protect against oxidative damage (Sestili et al., 2006; Hosamani et al., 2010; Berti et al., 2012; Saraiva et al., 2012). Creatine is hypothesized to function as an intracellular ATP buffer because it is phosphorylated near sites of ATP production by mitochondrial creatine kinase (MtCK) to generate phosphocreatine, which is then reversibly dephosphorylated by cytoplasmic creatine kinases for rapid ATP regeneration near sites of high utilization (Wyss and Kaddurah-Daouk, 2000). Intriguingly, oligodendrocytes have the highest capacity for the synthesis and utilization of creatine in the CNS (Manos et al., 1991; Molloy et al., 1992; Braissant et al., 2001; Tachikawa et al., 2004; Cahoy et al., 2008; Zhang et al., 2014). In addition, inborn errors of creatine metabolism frequently present with delayed myelination, as well as severe mental retardation, autistic-like behavior, motor disorder, and speech delay, suggesting a crucial role for creatine during brain development (Anselm et al., 2006; Barkovich, 2011). Despite its clinical relevance, the precise role of creatine in oligodendrocytes remains poorly understood.

Here, we investigated the role of creatine in oligodendrocyte function. We demonstrate that creatine increases oligodendrocyte mitochondrial ATP production directly and promotes oligodendrocyte survival under inflammatory conditions in vitro and after focal demyelination in vivo in mice. Moreover, we show that creatine does not affect the distribution of macrophages/microglia in demyelinated lesions, suggesting that the protective effect of creatine occurs independently of inflammatory modulation. These results suggest that the therapeutic administration of creatine may promote oligodendrocyte survival in MS.

\section{Materials and Methods}

Mice. C57BL/6J mice were obtained from The Jackson Laboratory and provided food and water ad libitum. Gamt ${ }^{-1+}$ mice were a kind gift from Dr. Dirk Isbrandt (University of Cologne). All experiments were performed according to protocols approved by the Institutional Animal Care and Use Committee at Georgetown University.

Chemicals and antibodies. Lipopolysaccharide (LPS; Escherichia coli 0111:B4) was obtained from InvivoGen. Creatine monohydrate (C3630), 3-guanidinopropionoic acid (GPA; G6878), and carbonyl cyanide 4-(trifluoromethoxy)phenylhydrazone (FCCP; 370-86-5) were obtained from Sigma-Aldrich. MitoTracker Red FM (M22425), tetramethylrhodamine, ethyl ester (TMRE; T669), and propidium iodide (PI) (P3566) were obtained from Thermo Fisher Scientific. Primary antibodies for immunohistochemistry (IHC) were as follows: rat anti-CD11b (1:100; AbD Serotec), rabbit anti-cleaved caspase-3 (1:100; Cell Signaling Technology), rabbit antiOlig2 (1:300; Millipore), rat anti-myelin basic protein (MBP, 1:200; AbD Serotec), mouse anti-CC1 (1:300; Millipore), and mouse anti-Nkx2.2 (1: 100; Developmental Studies Hybridoma Bank). Primary antibodies for immunocytochemistry (ICC) were as follows: rabbit anti-Olig2 (1:500; Millipore), rat anti-MBP (1:500; AbD Serotec), anti-GFAP (1:500; SigmaAldrich), mouse anti-CC1 (1:200; Millipore), and anti-PDGFR $\alpha$ (1:300; BD PharMingen). Alexa Fluor 488 or 594 secondary antibodies (Thermo Fisher
Scientific) were used at a concentration of 1:500. To label nuclei, cell and tissues were labeled with $1 \mu \mathrm{g} / \mathrm{ml}$ Hoechst in PBS for $5 \mathrm{~min}$ at room temperature (RT) (33342; Thermo Fisher Scientific).

Cell cultures. Mixed glia cultures were prepared from postnatal day 3 (P3) to P5 mouse cortices as described previously (Daniele et al., 2014) and maintained in DMEM-F12 containing 10\% FBS, 1\% penicillin-streptomycin $(\mathrm{P} / \mathrm{S}), 1 \%$ Fungizone (F/Z), and 1\% GlutaMAX for 2 weeks. Mixed glia cultures were switched to a serum-free medium for $24 \mathrm{~h}$ before initiating treatments. Primary OPCs were established by sequential shaking of confluent mixed glia cultures as described previously (Daniele et al., 2014). Primary oligodendrocyte lineage cell cultures were obtained from P3-P5 mouse cortices using magnetic activated cell sorting (MACS) with the Neural Tissue Dissociation Kit (130-092-628) and anti-O4 microbeads (130-096-670) according to the manufacturer's protocol (Miltenyi). Primary oligodendrocyte lineage cells were expanded in growth medium (DMEM-F12 with N2, B27, $\mathrm{P} / \mathrm{S}, \mathrm{F} / \mathrm{Z}, \mathrm{BSA}, \mathrm{FGF}$ and PDGF) and then differentiated using defined medium (DMEM-F12, N2, B27, P/S, F/Z, insulin, and T3) as described previously (Dincman et al., 2012). OLN-93 cells (Richter-Landsberg and Heinrich, 1996), originally from Dr. Christiane Richter-Landsberg (University of Oldenburg), were kindly provided by Dr. Wendy Macklin (University of Colorado) and maintained in DMEM containing 10\% FBS, $1 \% \mathrm{P} / \mathrm{S}, 1 \%$ $\mathrm{F} / \mathrm{Z}$, and $2 \mathrm{~mm}$ glutamine. All cultures were treated with $100 \mu \mathrm{M}$ creatine, $100 \mu \mathrm{M} 3$-guanidinopropionic acid, and/or $1 \mu \mathrm{g} / \mathrm{ml}$ LPS for 24-48 h.

Spinal cord demyelination. Focal demyelination was induced by injection of $1.0 \%$ lysolecithin (Sigma-Aldrich) diluted in sterile PBS into the spinal cord ventral funiculus of 9- to 12 -week-old mice. In all mice, $1 \times$ PBS or creatine monohydrate (25 ng) was coinjected along with $1.0 \%$ lysolecithin. The animals were killed for analysis at 5, 10, or $20 \mathrm{~d}$ after surgery. Both male and female mice were used for surgeries because no differences were observed between sexes.

Immunochemistry. Mice were perfusion fixed with $4 \%(\mathrm{w} / \mathrm{v})$ PFA (Sigma-Aldrich) in PBS. Spinal cord tissue was dissected and postfixed for $45 \mathrm{~min}$ in $4 \%$ PFA at RT. Tissue was cryoprotected in $20 \%(\mathrm{w} / \mathrm{v})$ sucrose (Sigma-Aldrich) in PBS at $4^{\circ} \mathrm{C}$ overnight before freezing in optimal cutting temperature medium on the surface of dry ice. Then, $12 \mu \mathrm{m}$ frozen spinal cord sections were collected on SuperFrostPlus slides (Stellar Scientific) using a cryostat and dried for $30 \mathrm{~min}$ before storage at $-80^{\circ} \mathrm{C}$. For in vitro experiments, cells were fixed with $4 \%$ (w/v) PFA and $120 \mathrm{~mm}$ sucrose for $20 \mathrm{~min}$ and then washed with PBS. Sections/cells were then incubated in blocking solution $(0.01 \% \mathrm{v} / \mathrm{v}$ Triton X-100 and 5\% goat serum in PBS) for $1 \mathrm{~h}$ at RT. Primary and secondary antibodies were diluted in PBS containing $0.01 \%(\mathrm{v} / \mathrm{v})$ Triton X-100 and $1 \%(\mathrm{w} / \mathrm{v})$ BSA and applied to sections/cells overnight at $4^{\circ} \mathrm{C}$. TBS was substituted for PBS when immunolabeling tissue sections. For detection of Nkx2.2 and $\mathrm{CC} 1$, mouse-on-mouse antigen retrieval was performed before immunohistochemistry according to the manufacturer's instructions (M.O.M. kit; Vector Laboratories).

Western blot. Cerebellum was dissected from mice at various postnatal time points. Proteins were harvested in lysate buffer ( $150 \mathrm{~mm}$ sodium chloride, $1 \%$ Triton $\mathrm{X}-100$, and $50 \mathrm{~mm}$ Tris, $\mathrm{pH} 8.0$ ), separated by SDS-PAGE, and immunoblotted using the following antibodies: mouse anti-VDAC (1:50; Abcam) and rabbit anti-Tom 20 (1:50; Santa Cruz Biotechnology). Proteins were detected using horseradish peroxidaseconjugated secondary antibodies and Pierce ECL Western blotting substrate. Protein expression was quantified by densitometry and represented as average protein expression normalized to $\beta$-Actin loading control.

Imaging and cell counting. For quantification of immunostaining, a blinded investigator used the ImageJ cell counter to count cells manually from low-magnification $(10-20 \times)$ images. For mixed glia cultures, data are represented as proportion of total Olig2 ${ }^{+}$cells to control for the heterogeneous density and growth of mixed glia cultures. For analysis of normal appearing white matter (NAWM) in uninjured spinal cord, cells were counted in spinal cord tissue directly adjacent to ventral lesions. For analysis of focal demyelinating spinal cord injury, cells were counted only in the lesioned area. Lesions were identified by abnormally high cell density in the ventral funiculus, as visualized by the accumulation of Hoechst-positive nuclei. Cell counts are expressed as percentage (ratio of cells expressing two markers divided by the number of cells expressing a 
single marker multiplied by 100) or density per square millimeter (number of cells expressing one or two markers divided by the area in square micrometers multiplied by $1,000,000$ ). A minimum of three sections from three mice were analyzed and the average proportion or density of cells was determined per mouse. The average and SEM was calculated for each group using Microsoft Excel.

Statistics. All statistics were performed using Prism. Data are represented as mean \pm SEM. Significance was determined using either twotailed Student's $t$ tests or one-way ANOVA with Bonferroni test for post hoc analysis. Statistical significance is reported as ${ }^{*} p \leq 0.05,{ }^{* *} p \leq 0.01$, ${ }^{* * *} p \leq 0.001,{ }^{* * *} p<0.0001$.

Mitochondrial labeling. To quantify mitochondrial density, primary oligodendrocyte cells cultured for $10 \mathrm{~d}$ in vitro (DIV) or primary OPCs cultured for 14 DIV were treated with PBS (control), creatine $(100 \mu \mathrm{M})$, or creatine and GPA $(100 \mu \mathrm{M})$ for $24 \mathrm{~h}$, after which mitochondria were labeled with MitoTracker Red (5 nM) for $30 \mathrm{~min}$ at $37^{\circ} \mathrm{C}$. Mature oligodendrocytes and OPCs were identified via immunostaining for MBP and PDGFR $\alpha$, respectively. Mitochondria outside the cell body were quantified using thresholded images in ImageJ. To measure mitochondrial membrane potential, purified oligodendrocyte lineage cells plated on a 96-well plate were differentiated until DIV 7 and treated with PBS or creatine $(100 \mu \mathrm{M})$ for $24 \mathrm{~h}$. Cells were incubated in $20 \mathrm{~nm}$ TMRE for $20 \mathrm{~min}$ and fluorescent intensity was measured using GloMax-Multi Detection System. As a control for TMRE sensitivity, cells were subsequently incubated with $20 \mu \mathrm{M}$ FCCP, a known ionophore uncoupler of oxidative phosphorylation, for 20 min to confirm a reduction in TMRE signal.

Seahorse extracellular flux analysis. $\mathrm{O}_{2}$ consumption rate of primary oligodendrocyte lineage cells was measured using an $\mathrm{XF}^{\mathrm{e}} 96$ Seahorse Bioscience Extracellular Flux Analyzer according to the manufacturer's protocol. Briefly, oligodendrocyte lineage cells were differentiated in defined medium and treated on DIV 3 with either creatine $(100 \mu \mathrm{M})$ or PBS for $24 \mathrm{~h}$. DIV 4 cells were washed in prewarmed assay medium for $1 \mathrm{~h}$ in a $\mathrm{CO}_{2}$-free $37^{\circ} \mathrm{C}$ incubator. The XF Cell Mito Stress Test Kit (Seahorse Bioscience, 103015-100) was used to quantify ATP production in $n=2$ wells/condition after sequential injections of oligomycin, FCCP, and rotenone/antimycin A. Oligomycin, a complev IV inhibitor, was injected to differentiate ATP-linked respiration from proton leak. FCCP, an uncoupler of ATP synthesis, was next injected to measure maximal respiratory rate. Finally, rotenone/antimycin A, an inhibitor of complex III, was injected to measure all nonmitochondrial sources of oxygen consumption (Seahorse Bioscience).

Membrane expansion analysis. To measure oligodendrocyte membrane expansion, purified oligodendrocyte lineage cells were differentiated until DIV 10 and treated with PBS (control), creatine $(100 \mu \mathrm{M})$, or creatine and GPA $(100 \mu \mathrm{M})$ for $24 \mathrm{~h}$ and immunostained for MBP. Fluorescent images were acquired using an EVOS Cell Imaging system and thresholded in ImageJ. Fractal dimensions of individual oligodendrocytes were quantified using the ImageJ Fractal Analysis plugin.

TUNEL. TUNEL was performed using Click-iT TUNEL Alexa Fluor 594 Imaging Assay for microscopy and HCS according to the manufacturer's instructions (Invitrogen).

EdU labeling. 5-Ethynyl-2'-deoxyuridine (EdU) labeling was performed using the Click-iT EdU Alexa Fluor 594 Imaging Kit according to the manufacturer's instructions (Invitrogen). EdU was added to cell cultures at a final concentration of $25 \mu \mathrm{M}$ beginning at the time of PBS or creatine treatment.

PI staining. Cells were incubated with $10 \mu \mathrm{g} / \mathrm{ml}$ PI for $20 \mathrm{~min}$ at $37^{\circ} \mathrm{C}$, washed once with prewarmed culture medium, and fixed for immunostaining.

RT-PCR. Reverse transcription PCR (RT-PCR) was conducted on complementary DNA (cDNA) obtained from cultures of MACS-purified oligodendrocyte lineage cells. The following mouse primer sequences were synthesized by MWG Operon: Agat forward (5'-TCA CGC TTC TTT GAG TAC CG-3'), Agat reverse (5' -TCA GTC GTC ACG AAC TTT CC-3'), Gamt forward ( $5^{\prime}$-TGG CAC ACT CAC CAG TTC A-3'), Gamt reverse (5'-GAC TGC CGC TAC TAT GCC TT- $\left.3^{\prime}\right), \mathrm{CrT}$ forward (5'-
TCC TGG CAC TCA TCA ACA G-3'), and CrT reverse (5'-ATG AAG CCC TCC ACA CCT AC-3').

\section{Results}

\section{Oligodendrocytes express components of the creatine biosynthesis and transport pathway}

Creatine synthesis occurs in a two-step reaction; L-arginine:glycine amidinotransferase (AGAT/GATM) first converts arginine and glycine into guanidinoacetate (GAA), which is then converted into creatine by guanidinoacetate-methyltransferase (GAMT). Oligodendrocytes express both AGAT and GAMT (Tachikawa et al., 2004; Braissant et al., 2010; Takasaki et al., 2010). To investigate how oligodendrocyte expression of these enzymes compares with that of other CNS cells, we searched for Agat (also known as Gatm) and Gamt in a publicly available RNA-sequencing transcriptome database of the mouse cerebral cortex (http://web.stanford.edu/group/ barres_lab/brain_rnaseq.html; Zhang et al., 2014) and graphed the resulting FPKM (fragments per kilobase of transcript sequence per million mapped fragments) values (Fig. 1A). Astrocytes, neurons, OPCs, newly formed oligodendrocytes, myelinating oligodendrocytes, microglia, and endothelial cells all express Agat. However, newly formed and myelinating oligodendrocytes express $29 \times$ more Gamt than all other CNS cells combined (Zhang et al., 2014), indicating that mature oligodendrocytes have a preferentially high capacity for endogenous creatine synthesis in the CNS. To address the function of creatine in oligodendrocytes, we established cultures of purified primary mouse oligodendrocytes by isolating $\mathrm{O}^{+}$oligodendrocyte lineage cells from early postnatal mice using MACS. The resulting cultures contain $94 \%$ Olig $2^{+}$cells, of which $7 \%$ differentiate into mature, MBP-positive oligodendrocytes after $3 \mathrm{~d}$ in defined medium (Dincman et al., 2012) (Fig. 1B). RT-PCR conducted on cDNA isolated from these cultures confirmed the expression of Agat, Gamt, and creatine transporter $1(\mathrm{CrT})$ (Fig. 1C), indicating that oligodendrocytes express all components of the creatine biosynthetic and transport pathway.

\section{Creatine increases oligodendrocyte mitochondria density, membrane potential, and ATP production}

Creatine addition has been shown to increase mitochondrial membrane potential and transport in Xenopus spinal neurons (Lee and Peng, 2008) and ATP production in hippocampal neurons (Li et al., 2004) and muscle (Walsh et al., 2001). To determine whether creatine also increases ATP production in oligodendrocyte mitochondria, MACS-purified oligodendrocyte lineage cells were treated with $1 \times$ PBS, $100 \mu \mathrm{M}$ creatine, or creatine and the competitive antagonist of $\mathrm{CrT}$, guanidinopropionic acid (GPA; $100 \mu \mathrm{M}$ ) for $24 \mathrm{~h}$. MitoTracker-Red was used to label mitochondria in mature oligodendrocytes, which were identified by expansive MBP staining (Fig. $1 D, E$ ). We found that creatine significantly increased the density of mitochondria in oligodendrocyte processes ( $n=12$ cells/condition; $p=0.0002)$. Moreover, this effect was completely abrogated by cotreatment with GPA (Fig. $1 F ; n=12$ cells/condition; $p=0.0002$ ). MitoTracker-Red was also used to quantify mitochondria density in PDGFR $\alpha^{+}$OPCs harvested by mixed glia shake off (Daniele et al., 2014) and treated with PBS, creatine, and creatine + GPA for $24 \mathrm{~h}$. Mitochondria within a $50 \mu \mathrm{m}$ region of a primary OPC process were quantified for analysis. We found that, compared with PBS (0.100 mitochondria/ $\mu \mathrm{m})$, mitochondria density was not significantly different in creatine $(0.106$ mitochondria/ $\mu \mathrm{m})$ or creatine + GPA ( 0.08 mitochondria/ $\mu \mathrm{m})$-treated OPC processes (data not shown), indicating that creatine affects mature oligodendrocyte mitochondria density specifically within the lin- 

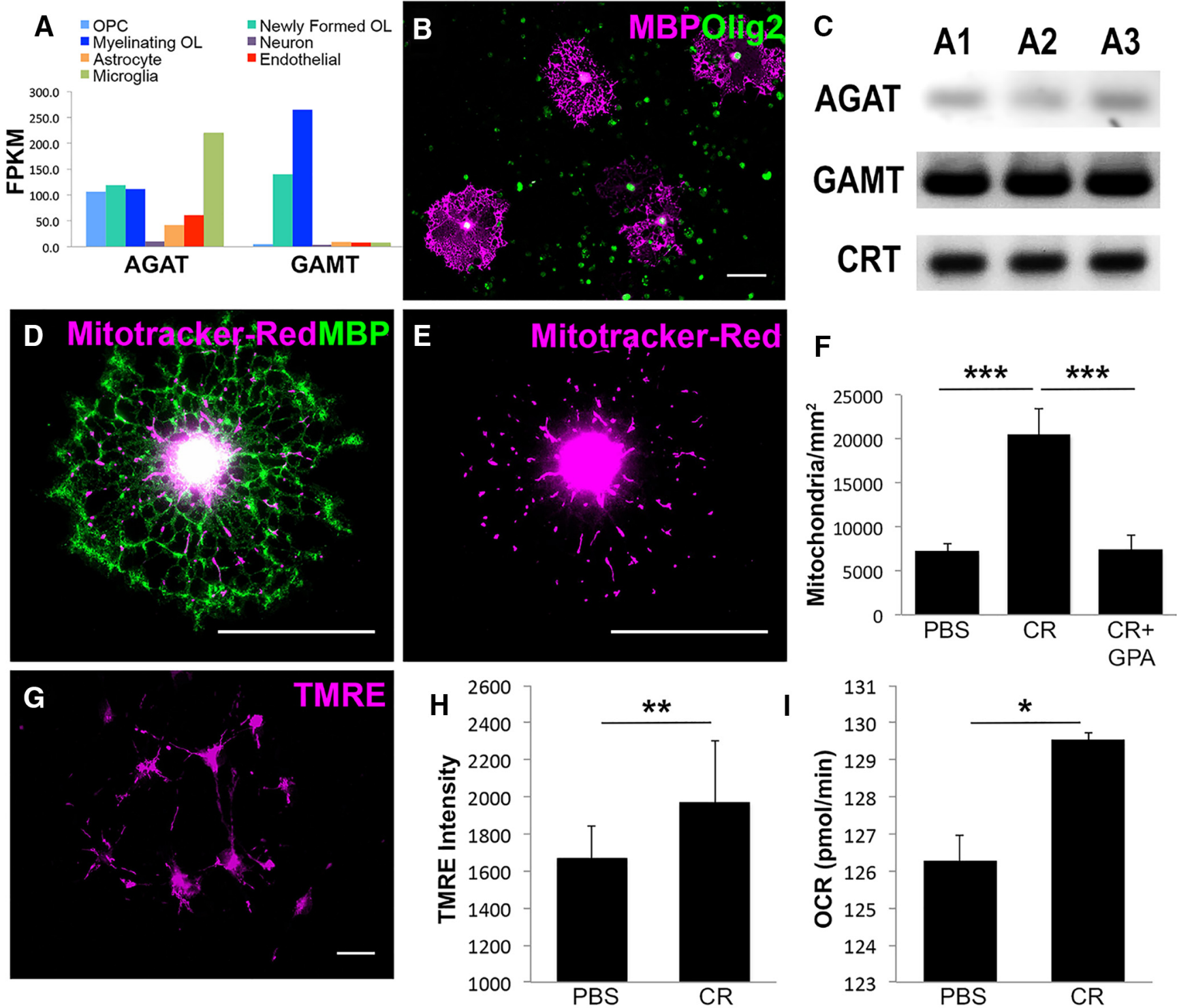

MBP: Mature oligodendrocytes Olig2: Oligodendrocyte lineage cells Mitotracker Red: Mitochondria

Figure 1. Creatine increases oligodendrocyte mitochondria density, membrane potential, and ATP production. $A$, Graphical representation of cell-specific Agat and Gamt RNA levels obtained from a publicly available RNA-sequencing transcriptome database (http://web.stanford.edu/group/barres_lab/). FPKM represents fragments per kilobase of transcript sequence per million mapped fragments (Zhang et al., 2014). B, DIV 10 oligodendrocyte lineage cells cultured via MACS. OPCs are 0 lig2 ${ }^{+}$(green) and mature oligodendrocytes are double positive for 0 lig2 ${ }^{+}$and $\mathrm{MBP}^{+}$(magenta) $(20 \times)$ C, MACS-purified oligodendrocytes from $n=3$ mice (A1-A3) express transcripts for the creatine biosynthetic enzymes, Agat and Gamt, and the creatine transporter, CrT, via RT-PCR. D, MBP ${ }^{+}$ (green) oligodendrocyte with mitochondria (magenta) labeled with MitoTracker Red. $\boldsymbol{E}$, Same image shown in $\boldsymbol{D}$ displaying mitochondria (magenta) only. $\boldsymbol{F}$, Density of mitochondria per square millimeter counted in the processes of $\mathrm{MBP}^{+}$oligodendrocytes in MACS-purified oligodendrocyte lineage cell cultures expanded until DIV 7 and differentiated until DIV 9 , when they were treated with PBS, $100 \mu \mathrm{m}$ creatine (CR), or CR + $100 \mu \mathrm{m}$ GPA for 24 h. $n=12$ cells/condition; one-way ANOVA with Bonferroni post hoc test. G, Live-cell TMRE (magenta) image showing labeled mitochondria in living oligodendrocytes. $\boldsymbol{H}$, Quantification of average fluorescent intensity of TMRE signal from oligodendrocyte lineage cell cultures expanded for $24 \mathrm{~h}$ and differentiated until DIV 3 , when they were treated with PBS or CR for $24 \mathrm{~h} . n=2$ wells/condition; Student's $t$ test. I, Results of Seahorse extracellular flux analysis showing average oxygen consumption rate (OCR) in picomoles per minute during ATP production in oligodendrocyte lineage cell cultures expanded for $24 \mathrm{~h}$ and differentiated until DIV 3 , when they were treated with PBS or CR for $24 \mathrm{~h} . n=2$ wells/condition; Student's $t$ test. Data are represented as mean \pm SEM. Scale bars, $50 \mu \mathrm{m}$. Brightness and contrast were adjusted for visualization. ${ }^{*} p<0.05$, ${ }^{* *} p<0.01,{ }^{* * *} p<0.001$, ${ }^{* * * *} p<0.0001$.

eage. Because density is linked to mitochondrial activity (Morris and Hollenbeck, 1993), we next examined the effect of creatine on mitochondrial activity in oligodendrocytes. Mitochondria within primary oligodendrocyte lineage cells were labeled with TMRE (Fig. $1 G$ ), a cationic dye that accumulates in mitochondria relative to their membrane potential $(\psi \mathrm{m})$ and serves as a proxy for ATP production such that its fluorescent intensity increases as ATP is produced via oxidative phosphorylation (Perry et al., 2011). We found that oligoden- drocyte lineage cells treated with creatine for 24 h had significantly higher TMRE intensity compared with cells treated with PBS (Fig. $1 H ; n=2$ wells/condition; $p=0.0016$ ), suggesting that the creatine treatment increases oligodendrocyte mitochondrial activity. We confirmed this finding using Seahorse extracellular flux analysis, which measures oxygen consumption as an indicator of mitochondrial respiration. We found that creatine-treated oligodendrocyte lineage cells displayed significantly increased ATP production compared 
with controls (Fig. $1 I ; n=2$ wells/condition; $p=0.0454$ ). Together, these findings suggest that creatine enhances mitochondrial function directly in primary oligodendrocytes.

\section{Creatine treatment enhances oligodendrocyte lineage cell survival, but does not affect oligodendrocyte membrane expansion or differentiation}

Myelination is a highly energy-demanding process, requiring an estimated $3.30 \times 10^{23}$ ATP molecules/g of myelin synthesized (Harris and Attwell, 2012). To determine whether increased ATP production in creatine-treated oligodendrocytes stimulates membrane expansion, MACS-purified oligodendrocyte lineage cells were treated with PBS (control), creatine (creatine), or creatine + GPA for $24 \mathrm{~h}$. Expansion of MBP-positive membranes was measured using fractal analysis, a quantitative measurement of morphological complexity that has been used previously to assess differentiation of oligodendrocyte lineage cells in vitro (Behar, 2001). We found that the fractal dimension of all oligodendrocytes was in the range of those previously reported (Fig. 2A). However, the average fractal dimension of oligodendrocytes was not significantly different across treatment groups compared with control (Fig. 2B), suggesting that creatine does not affect oligodendrocyte membrane expansion in vitro.

To test whether creatine addition stimulates differentiation of OPCs into oligodendrocytes, we quantified the proportions of OPCs and mature oligodendrocytes in primary mixed glia cultured in serum-free medium with PBS or creatine for 24 or $48 \mathrm{~h}$ (Fig. 2C). Creatine treatment did not affect the proportions of OPCs (Fig. 2D) or oligodendrocytes (Fig. 2E) at either time point ( $n=9$ images/condition), suggesting that creatine does not stimulate differentiation of OPCs into oligodendrocytes. Because no difference was observed in the proportions of oligodendrocyte lineage cells after creatine treatment, we investigated whether creatine affected the homeostatic turnover of oligodendrocyte lineage cells (Hughes et al., 2013) by assessing the overall proportion of cells undergoing proliferation and cell death. Primary mixed glia were treated with PBS or creatine for $48 \mathrm{~h}$ in the presence of the thymidine analog EdU to label proliferating cells engaged in DNA synthesis. Quantification of cells immunostained for EdU and PDGFR $\alpha$ revealed that creatine treatment resulted in a significant reduction in the proportion of proliferating oligodendrocyte precursor cells (Fig. $2 F, G ; n=10$ images/ condition; $p=0.0439$ ). To determine whether creatine affects oligodendrocyte lineage cell death, mixed glia treated with PBS or creatine for $48 \mathrm{~h}$ were incubated with PI, a membraneimpermanent DNA-intercalating agent used for the identification of dying cells. We found that creatine treatment reduced the proportion of dying oligodendrocyte lineage cells significantly (Fig. $2 H, I ; n=5$ images/condition; $p=0.0002$ ), suggesting that creatine promotes their survival. TUNEL analysis for the detection of fragmented DNA in dying $\mathrm{CC}^{+}$oligodendrocytes further demonstrated that creatine improved the survival of mature oligodendrocytes significantly (Fig. $2 \mathrm{~J}, \mathrm{~K} ; n=12$ images/condition; $p=0.0070$ ). To investigate the direct effect of creatine on oligodendrocyte survival, MACS-purified oligodendrocyte lineage cells were treated with PBS or creatine for $24 \mathrm{~h}$. Creatine-treated cultures exhibited a smaller proportion of dying oligodendrocytes $\left(\% \mathrm{PI}^{+} \mathrm{MBP}^{+} / \mathrm{MBP}^{+}\right)$compared with PBS-treated cultures $(16.37 \%$ vs $45.27 \% ; n=6$ images/condition; $p=0.0273$, Student's $t$ test; data not shown), demonstrating a direct prosurvival effect of creatine on mature oligodendrocytes.

\section{Creatine promotes oligodendrocyte cell survival after inflammatory insult}

The prosurvival effect of creatine (Fig. $2 \mathrm{H}-\mathrm{K}$ ) prompted us to test whether creatine also promotes oligodendrocyte survival under inflammatory conditions. We first established a robust assay of inflammation-mediated oligodendrocyte cell death using the rodent oligodendroglia cell line OLN-93 (Richter-Landsberg and Heinrich, 1996). To mimic a proinflammatory environment, OLN-93 cells were treated with conditioned media taken from RAW 264.7 macrophage/monocyte(s) treated with PBS or LPS. LPS is a potent activator of Toll-like 4 receptor (TLR4) that stimulates macrophages/monocytes to release proinflammatory cytokines and is a known activator of oligodendrocyte cell death in mixed cultures (Li et al., 2005). Cell death analysis by TUNEL assay showed that the addition of conditioned medium from LPS-activated macrophages to OLN-93 cells increased cell death significantly compared with the control conditioned medium (Fig. $3 A-D ; n=10$ images/condition; $p<0.0001$ ). Moreover, the addition of creatine with the LPS-conditioned medium resulted in a dramatic reduction of OLN-93 cell death compared with PBS addition (Fig. $3 A, D ; n=10$ images/condition; $p=0.0008$ ), suggesting that creatine has a direct prosurvival effect on oligodendrocytes. We next examined the prosurvival effect of creatine on primary oligodendrocytes by treating mixed glia cultures with PBS, LPS, or LPS + creatine, followed by coimmunostaining analysis with antibodies against PDGFR $\alpha, \mathrm{CC} 1$, and Olig2. Compared with PBS, LPS treatment significantly reduced the proportion of $\mathrm{CCl}^{+} \mathrm{Olig} 2^{+}$mature oligodendrocytes (Fig. $3 E$, white bars; $n=10$ images/condition; $p=0.0258$ ). This effect was abrogated by cotreatment with creatine (Fig. $3 E$, white bars; $n=10$ images/condition; $p=0.0006$ ). As demonstrated previously ( $\mathrm{Li}$ et al., 2008; Skripuletz et al., 2011), LPS treatment resulted in a higher proportion of PDGFR $\alpha^{+}$Olig2 ${ }^{+}$OPCs compared with PBS (Fig. 3E, light gray bars; $n=10$ images/condition; $p=$ 0.019 ), an effect that was abrogated by cotreatment with creatine (Fig. 3E, light gray bars; $n=10$ images/condition; $p=0.017$ ). Additionally, whereas LPS increased apoptosis of both OPCs (Fig. 3F, $n=8$ images/condition; $p=0.016$ ) and oligodendrocytes (Fig. $3 G ; n=10$ images/condition; $p=0.0482$ ), cotreatment with creatine specifically ameliorated apoptosis of oligodendrocytes (Fig. 3G; $n=10$ images/condition; $p=$ 0.0179 ), but had no effect on OPC death, which remained significantly elevated compared with PBS (Fig. 3F; $n=10$ images/ condition; $p=0.010$ ). The simultaneous increase in OPC proportion and apoptosis is mediated by increased OPC proliferation under LPS treatment $(n=10$ images/condition; $p=$ 0.023 , Student's $t$ test; data not shown), suggesting that the OPC response is largely homeostatic. Overall, these results further suggest that creatine promotes oligodendrocyte survival under proinflammatory conditions.

\section{Reduced oligodendrocyte density in Gamt-deficient focal demyelinating lesions can be rescued by creatine injection} We next investigated whether creatine deficiency in vivo impairs oligodendrocyte viability by analyzing mice lacking the creatinesynthesizing enzyme GAMT $\left(\mathrm{Gamt}^{-1-}\right)$. These mice are completely deficient in endogenously synthesized creatine, but do not display the severe learning deficits characteristic of human creatine deficiency (Schmidt et al., 2004). We selected this model to ensure absence of peripherally synthesized creatine in the CNS (Schmidt et al., 2004; Torremans et al., 2005) and because oligodendrocytes are the only CNS cell type expressing high levels of Gamt (Zhang et al., 2014; Fig. 1A). Western blot analysis 
A
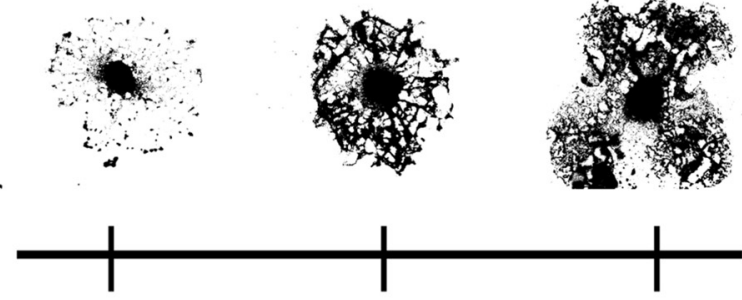

1.53

C

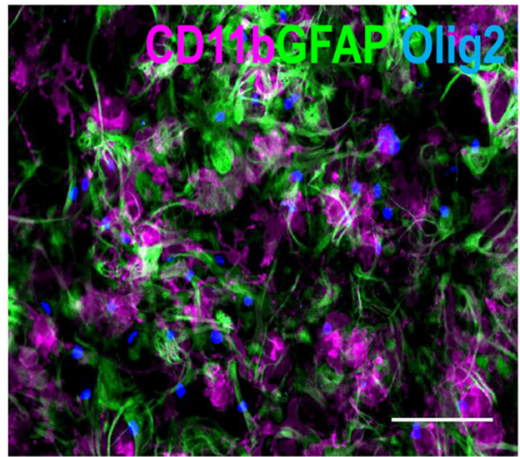

$\mathbf{F}$

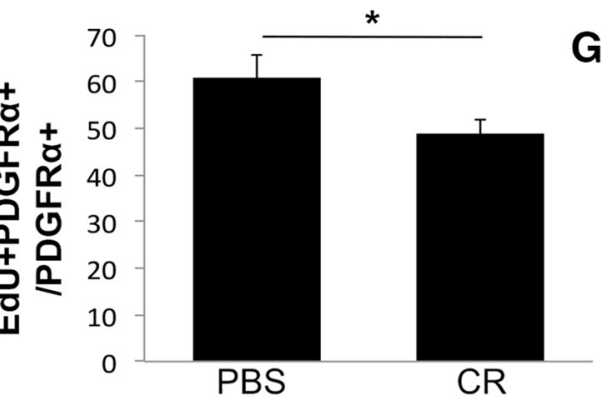

H
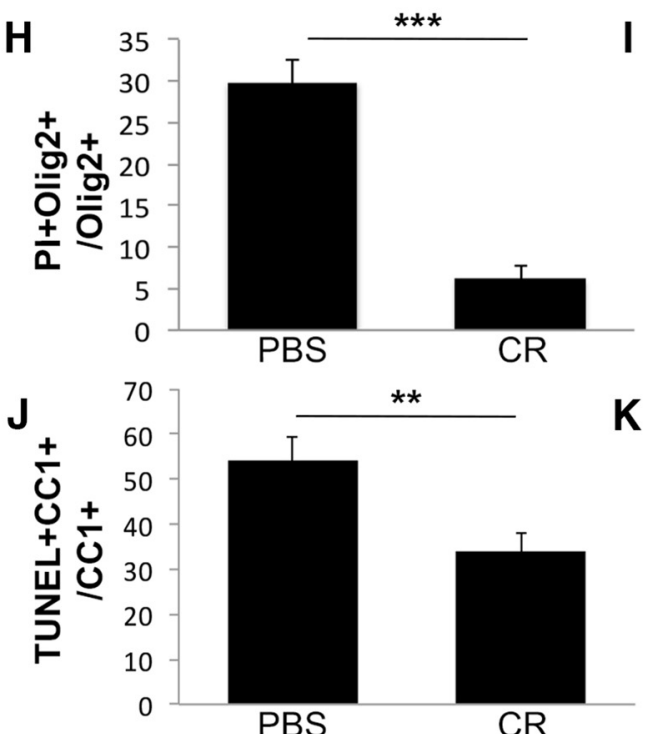

1.73

D

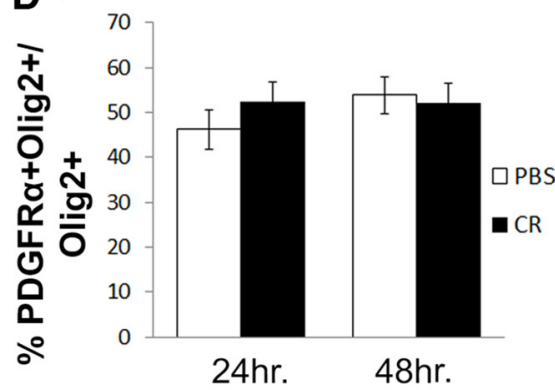

G
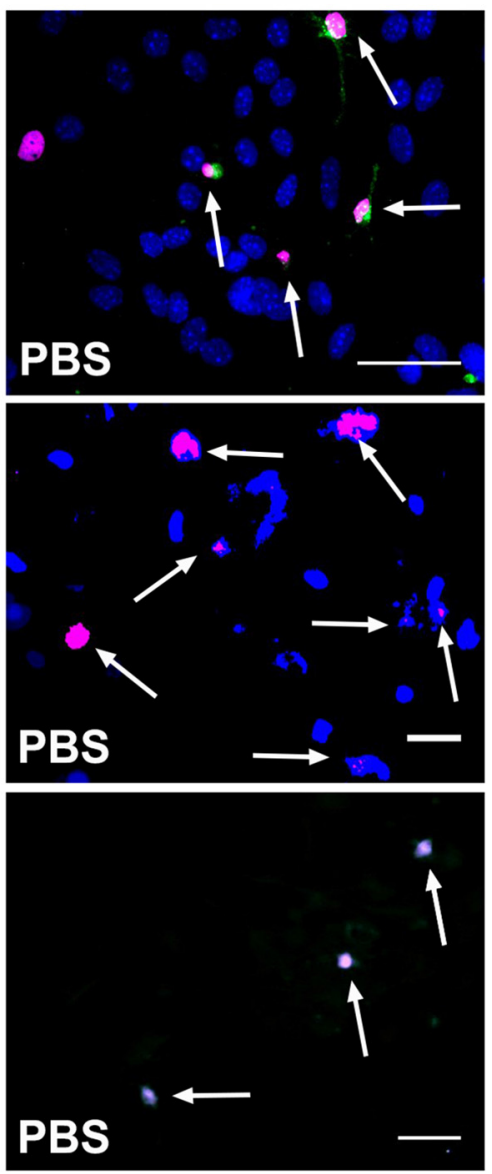

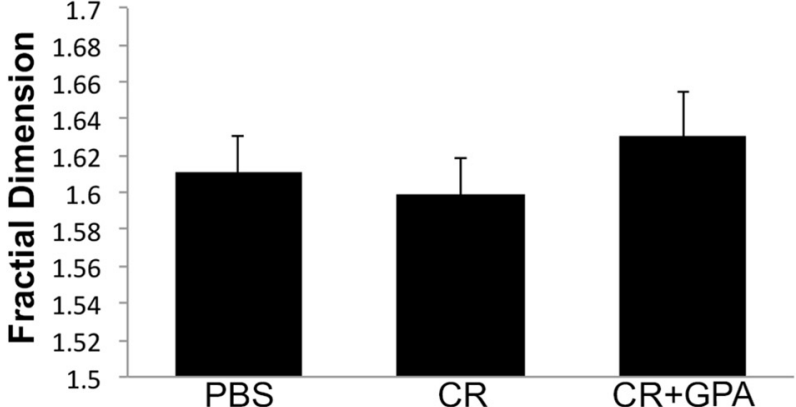

E
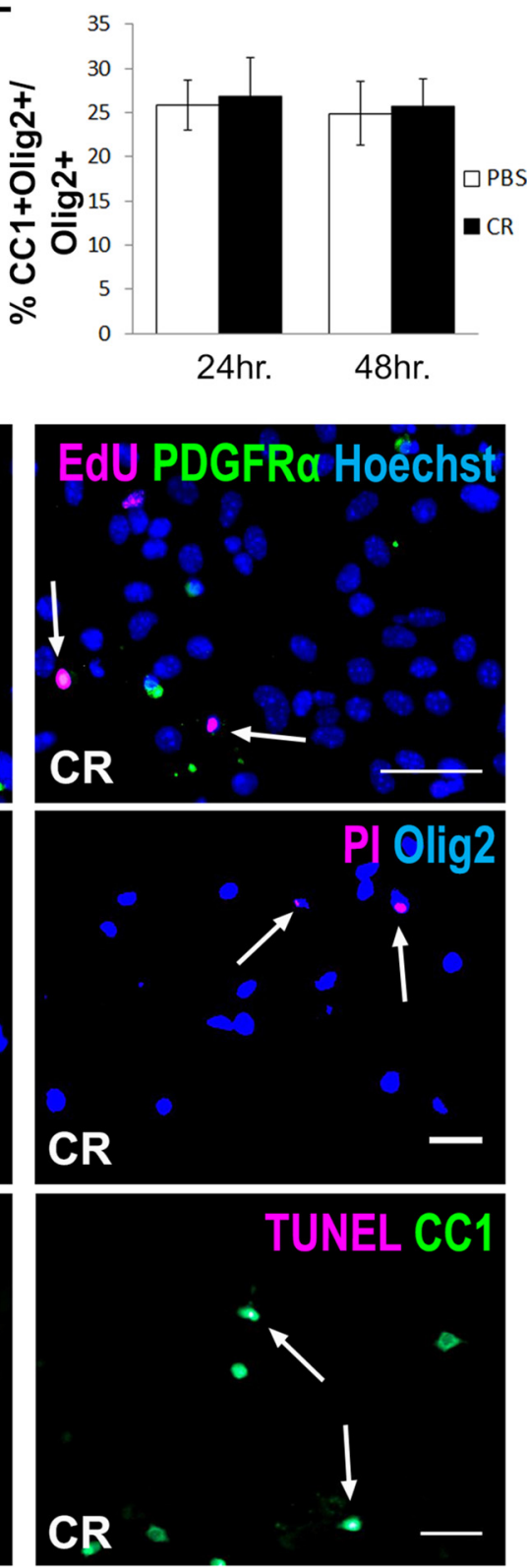

PBS

$\mathrm{CR}$

CD11b: Microglia GFAP: Astrocytes Olig2: Oligodendrocyte lineage cells

EdU: Proliferating cells Propodium lodide (PI): Dying cells

Figure 2. Creatine treatment enhances oligodendrocyte lineage cell survival, but does not affect oligodendrocyte membrane expansion or differentiation. $\boldsymbol{A}$, Representative images of MACScultured primary oligodendrocytes at different stages of membrane expansion and their associated fractal dimension values. $\boldsymbol{B}$, Fractal dimensions of primary oligodendrocytes treated with PBS, $100 \mu \mathrm{m}$ creatine (CR), or CR $+100 \mu \mathrm{m}$ GPA for $24 \mathrm{~h}$. C, Representative image of primary mouse mixed glia cultures containing microglia (CD11 $\mathrm{b}^{+}$; magenta), astrocytes (GFAP ${ }^{+}$; green), and oligodendrocyte lineage cells (Olig2 ${ }^{+}$; blue). Scale bar, $100 \mu \mathrm{m}$. D, Quantification of immunostaining showing the percentage of OPCs (PDGFR $\alpha^{+}$Olig2 ${ }^{+}$) of total oligodendrocyte lineage cells $\left(0\right.$ lig2 ${ }^{+}$) after 24 or $48 \mathrm{~h}$ of treatment with PBS or (R. $n=9$ images/condition; Student's $t$ test. $E$, Quantification of immunostaining showing the percentage of mature oligodendrocytes $\left(\mathrm{CC}^{+}\right.$Olig2 $2^{+}$) of total oligodendrocyte lineage cells (Olig2 ${ }^{+}$) after 24 or $48 \mathrm{~h}$ ot treatment with PBS or CR. $n=9$ images/condition; Student's $t$ test. $\boldsymbol{F}$, (Figure legend continues.) 

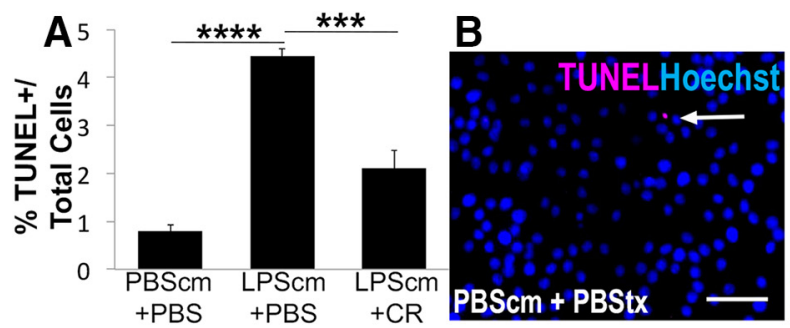

C

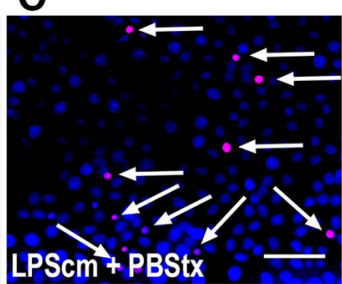

D

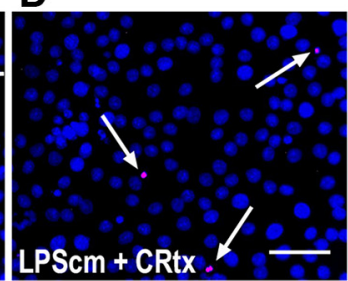

E

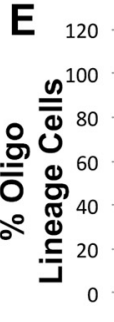

$\mathbf{F}$
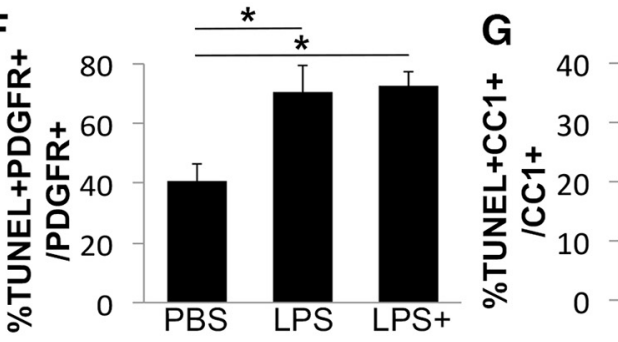

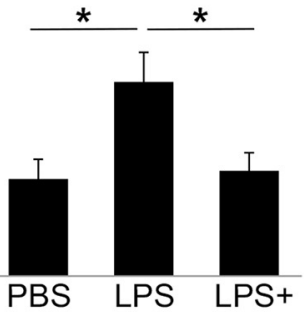

H

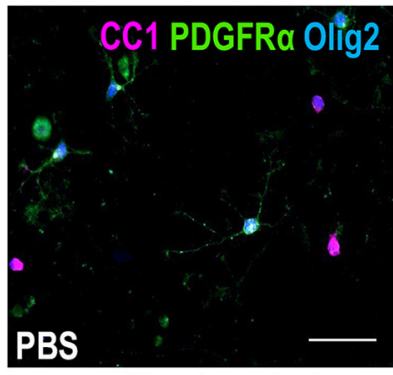

CR
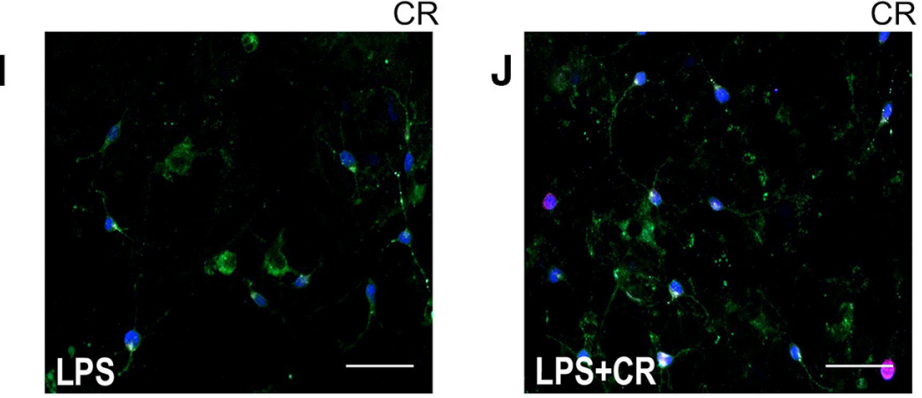

Hoechst: Nuclear counterstain TUNEL: Dying cells CC1: Mature oligodendroytes

PDGFRa: OPCs Olig2: Oligodendrocyte Lineage Cells

Figure 3. Creatine promotes oligodendrocyte cell survival following inflammatory insult. $A$, Quantification of TUNEL assay and immunostaining showing the percentage of dying OLN cells (TUNEL $^{+}$Hoechst $^{+}$) of total cells (Hoechst ${ }^{+}$) after treatment. 0 LN-93 cells were treated with PBS or $100 \mu$ m creatine (CR) for $24 \mathrm{~h}$ while simultaneously being exposed to conditioned medium (cm) from RAW cells treated with either PBS (PBScm) or $1 \mu \mathrm{g} / \mathrm{ml}$ LPS (LPScm) the day prior. $n=10$ images/condition; one-way ANOVA with Bonferroni post hoc test. $\boldsymbol{B}-\boldsymbol{D}$, TUNEL assay (magenta) depicting dying OLN-93 cells (TUNEL ${ }^{+}$Hoechst ${ }^{+}$) in cultures treated with PBScm $+\mathrm{PBS}(\boldsymbol{B}), \operatorname{LPS} \mathrm{cm}+\mathrm{PBS}(\boldsymbol{C})$, or LPS $\mathrm{cm}+\mathrm{CR}(\boldsymbol{D})$. E, Quantification of immunostaining showing the percentage of total 0 lig2 $2^{+}$cells (dark gray) represented by OPCS (PDGFR $\alpha^{+}$Olig2 ${ }^{+}$; light gray) and mature oligodendrocytes $\left(C C 1^{+}\right.$Olig2 ${ }^{+}$; white) after $24 \mathrm{~h}$ of treatment with PBS, LPS, or LPS + CR. $n=10$ images/condition; one-way ANOVA with Bonferroni post hoc test. $F$, Quantification of the percentage of dying OPCs (TUNEL ${ }^{+}$PDGFR $\alpha^{+}$) out of total OPCs (PDGFR $\alpha^{+}$) after $24 \mathrm{~h}$ of treatment with $\mathrm{PBS}, \mathrm{LPS}$, or LPS + CR. $n=10$ images/condition; one-way ANOVA with Bonferroni post hoc test. G, Quantification of the percentage of dying oligodendrocytes (TUNEL ${ }^{+} C\left(1^{+}\right)$of total oligodendrocytes $\left(C C 1^{+}\right)$after $24 \mathrm{~h}$ of treatment with PBS, LPS, or LPS + CR. $n=10$ images/condition; one-way ANOVA with Bonferroni post hoc test. $\boldsymbol{H}-\boldsymbol{J}$, Immunostaining for mature oligodendrocytes $\left(\mathrm{CC}^{+}\right.$Olig2 $\left.{ }^{+}\right)$and OPCS (PDGFR $\alpha^{+}$Olig2 $\left.2^{+}\right)$in primary mouse mixed glial cultures treated with PBS $(\boldsymbol{H})$, LPS $(\boldsymbol{I})$, or LPS + CR $(\boldsymbol{J})$ for $24 \mathrm{~h}$. Data are represented as mean \pm SEM. Scale bars, $50 \mu \mathrm{m}$. Brightness and contrast were adjusted for visualization. ${ }^{*} p<0.05,{ }^{* *} p<0.01,{ }^{* * *} p<0.001,{ }^{* * * *} p<0.0001$.

demonstrates that GAMT protein is undetectable in cortical and cerebellar protein lysates of $\mathrm{Gamt}^{-1-}$ mice. Moreover, we found that Gamt ${ }^{-1-}$ mice had normal expression of oligodendrocyte-specific proteins (Olig2, PLP, and MBP) at P30. Total

$\leftarrow$

(Figure legend continued.) Quantification of immunostaining showing the percentage of proliferating OPCS (Edu ${ }^{+}$PDGFR $\alpha^{+}$) out of total OPCS (PDGFR $\left.\alpha^{+}\right)$after $48 \mathrm{~h}$ of treatment with PBS or CR. $n=10$ images/condition;Student'sttest. G, Representative images of EdU (magenta) immunostaining showing proliferating OPCs ( $\mathrm{PDGFR} \alpha^{+}$, green) in mixed glia cultures after $48 \mathrm{~h}$ of treatment with PBS or CR. White arrows indicate Edu ${ }^{+}$PDGFR $\alpha^{+}$cells. Scale bars, $50 \mu \mathrm{m}$. $\boldsymbol{H}$, Quantification of immunostaining showing the percentage of dying oligodendrocyte lineage cells $\left(\mathrm{PI}^{+}\right.$Olig2 $\left.{ }^{+}\right)$of total oligodendrocyte lineage cells (Olig2 ${ }^{+}$) after $48 \mathrm{~h}$ of treatment with PBS or CR. $n=5$ images/condition; Student's t test. I, Representative images of PI (magenta) immunostaining showing dying oligodendrocyte lineage cells (Olig2 ${ }^{+}$, blue) in mixed glia cultures after $48 \mathrm{~h}$ of treatment with PBS or CR. White arrows indicate $\mathrm{PI}^{+}$Olig2 ${ }^{+}$cells. Data are represented as mean \pm SEM. Scale bars, $50 \mu \mathrm{m}$.J, Quantification of TUNEL assay and immunostaining showing the percentage of dying oligodendrocytes (TUNEL $\left.{ }^{+} \mathrm{CC}^{+}\right)$of total oligodendrocytes $\left(\mathrm{CC}^{+}\right)$after 48 h of treatment with PBS or CR. $n=12$ images/condition; Student's $\boldsymbol{t}$ test. $\boldsymbol{K}$, Representative images of TUNEL (magenta) assay and immunostaining of dying oligodendrocytes $\left(\mathrm{CC}^{+}\right.$, green) in mixed glia cultures after $48 \mathrm{~h}$ of treatment with PBS or CR. White arrows indicate TUNEL ${ }^{+} \mathrm{CC}^{+}$cells. ${ }^{*} p<0.05,{ }^{* *} p<0.01,{ }^{* * *} p<0.001$, **** $p<0.0001$. levels of the mitochondrial-specific proteins Tom20 and VDAC were also not different between $\mathrm{Gamt}^{+/+}$and Gamt $^{-1-}$ mice (data not shown).

To investigate whether creatine plays a role in oligodendrocyte survival during remyelination in vivo, we analyzed a previously published remyelination transcriptome from the rat CNS (Huang et al., 2011). Similar to other highly expressed oligodendrocyte genes, including myelin oligodendrocyte glycoprotein $(\mathrm{Mog})$ and myelin basic protein (Mbp), Gamt was significantly differentially upregulated during oligodendrocyte differentiation and remyelination at 14 and $28 \mathrm{~d}$ post lesion (dpl), respectively ( $p=0.0019$; Huang et al., 2011). Considering the time course of this upregulation, we hypothesized that Gamt-deficient oligodendrocytes would have impaired viability during remyelination. To test this, we used a mouse model of focal demyelination in which the toxin lysolecithin is microinjected into the mouse spinal cord white matter. This model was selected due to the known lesion location and well documented time course in which cell death and inflammation, oligodendrocyte differentiation, and remyelination occur at $\sim 5,10$, and $20 \mathrm{dpl}$, respectively (Pavelko et al., 1998; Bieber et al., 2003; Arnett et al., 2004). Focal spinal 

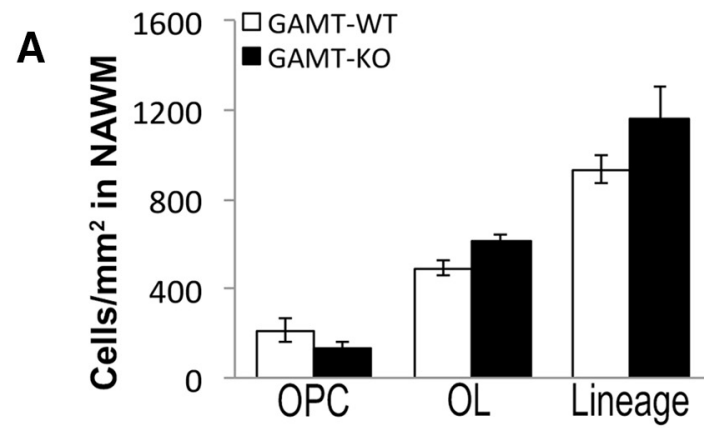

C
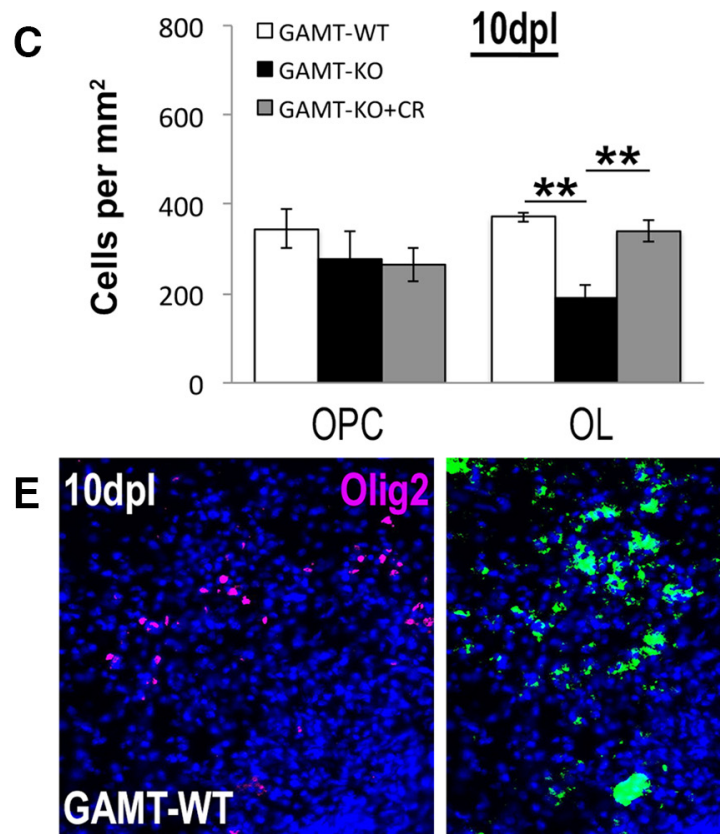

GAMT-KO
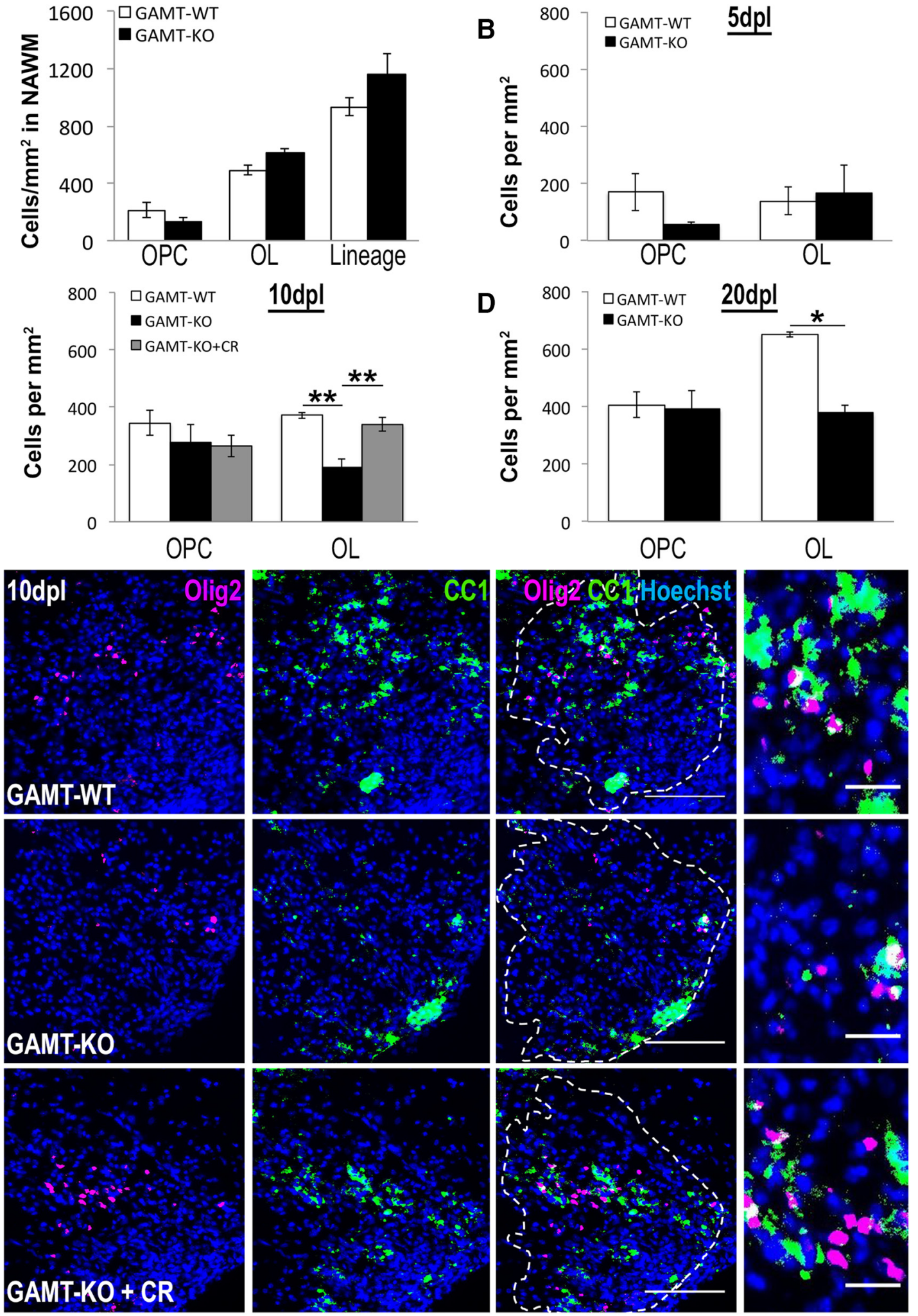

Hoechst: Nuclear counterstain Olig2: Oligodendroyte lineage cells CC1: Mature oligodendroytes

Figure 4. Reduced oligodendrocyte density in Gamt-deficient focal demyelinating lesions can be rescued by creatine injection. $A$, Quantification of immunostainings for $0 \mathrm{PCs}\left(\mathrm{Nkx2.2^{+ }}\right.$ Olig2 ${ }^{+}$), oligodendrocytes $\left(0 \mathrm{~L} ; \mathrm{CC}^{+}\right.$Olig2 ${ }^{+}$), and total oligodendrocyte lineage cells (Lineage; Olig2 ${ }^{+}$) per square millimeter in NAWM in Gamt ${ }^{+/+}\left(\right.$GAMT-WT) and Gamt ${ }^{-1-}($ GAMT-KO) mice. $\boldsymbol{B}-\boldsymbol{D}$, Quantification of immunostainings for OPCs and OLs per square millimeter at $5(\boldsymbol{B}), 10(\boldsymbol{C})$, and $20 \mathrm{dpl}(\boldsymbol{D})$ in GAMT-WT, GAMT-KO, and Gamt ${ }^{-1-}$ mice coinjected with $25 \mathrm{ng}$ of creatine (GAMT-KO + CR; 10 dpl only). $n=3$ mice/condition; one-way ANOVA with Bonferroni post hoc test performed in $C$, Student's $t$ test performed in $\boldsymbol{D}$. E, Representative immunostainings of mature oligodendrocytes double positive for 0 lig2 (magenta) and CC1 (green) at $10 \mathrm{dpl}$. Data are represented as mean \pm SEM. Long scale bars, $100 \mu \mathrm{m}$; short scale bars, $25 \mu \mathrm{m}$. Brightness and contrast were adjusted for visualization. ${ }^{*} p<0.05,{ }^{* *} p<0.01$. 

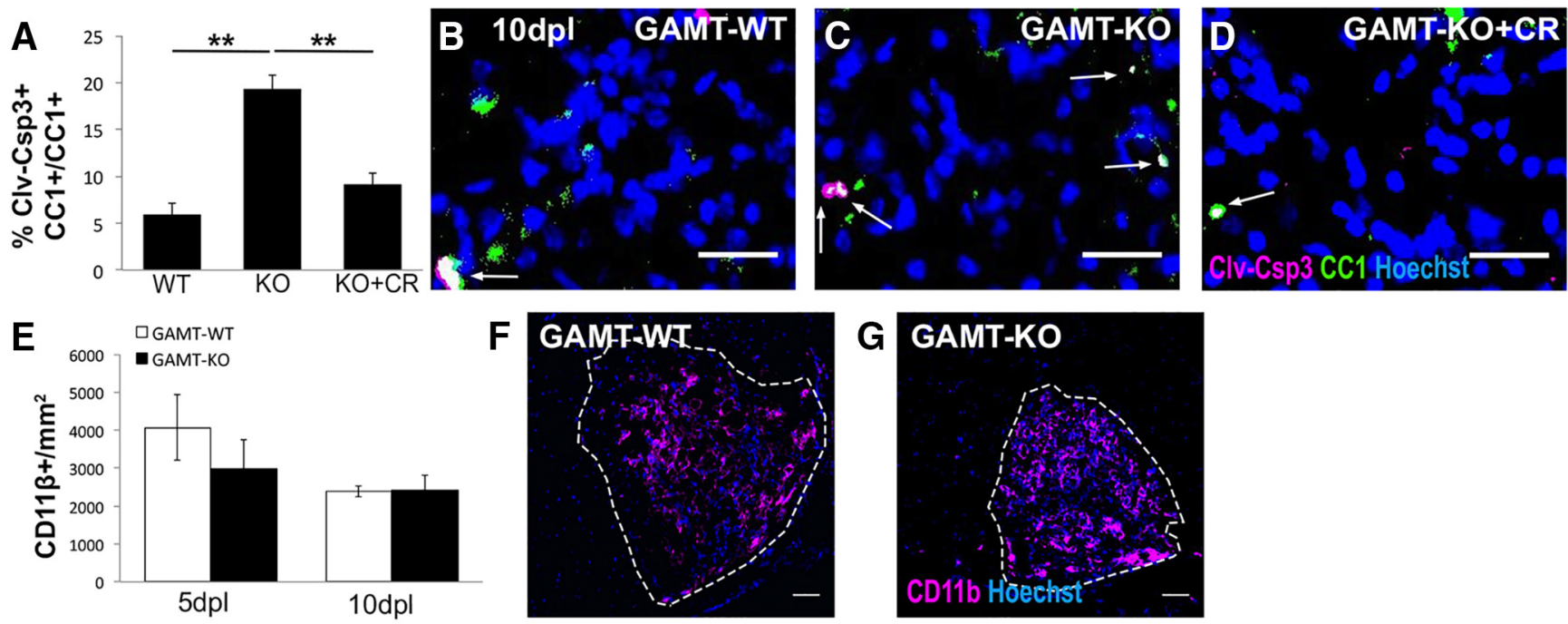

Clv-Csp3: Cleaved Caspase-3 CC1: Mature oligodendroytes Hoechst: Nuclear counterstain CD11b: Macrophage/monocytes

Figure 5. Gamt-deficient oligodendrocytes exhibit reduced survival after focal spinal cord demyelination. A, Quantification of immunostaining showing the proportion of oligodendrocytes positive for cleaved caspase-3 (Clv-Csp3 ${ }^{+} \mathrm{CC}^{+}$) of total oligodendrocytes $\left(\mathrm{CC}^{+}\right)$at $10 \mathrm{dpl}$ in Gamt ${ }^{+/+}$(GAMT-WT), Gamt ${ }^{-1-}$ (GAMT-K0), and Gamt ${ }^{-1-}$ mice treated with $25 \mathrm{ng}$ of $\mathrm{Creatine}$ (GAMT-KO + (R). $n=3$ mice/condition; one-way ANOVA with Bonferroni post hoc test. $\boldsymbol{B}-\boldsymbol{D}$, Representative immunostainings of dying oligodendrocytes in (GAMT-WT) (B), GAMT-KO (C), and GAMT-K0 + CR (D) lesions at $10 \mathrm{dpl}$. White arrows indicate cells double positive for Clv-Csp3 and CC1. Scale bars, $25 \mu \mathrm{m}$. E, Quantification of immunostaining for CD11 $\mathrm{b}^{+}$cells per square millimeter in GAMT-WT and GAMT-KO lesions at 5 and $10 \mathrm{dpl} . n=3$ mice/condition. $\boldsymbol{F}, \boldsymbol{G}$, Representative immunostainings of macrophages/microglia (CD11b ${ }^{+}$; magenta) in GAMT-WT (F) and GAMT-KO (G) lesions at $5 \mathrm{dpl}$. Scale bars, $50 \mu \mathrm{m}$. Data are represented as mean \pm SEM. Brightness and contrast were adjusted for visualization. ${ }^{*} p<0.05,{ }^{* *} p<0.01$.
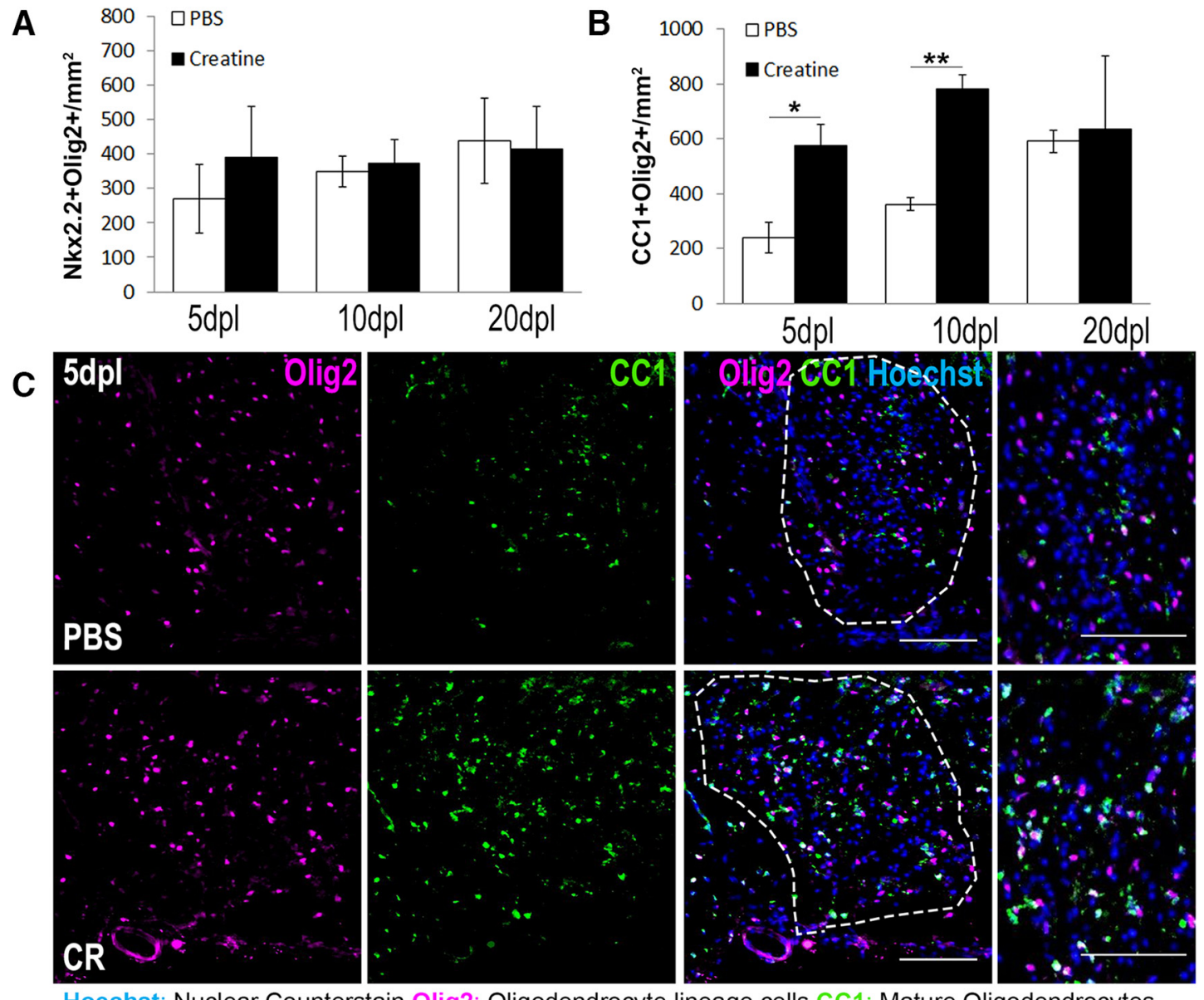

CR

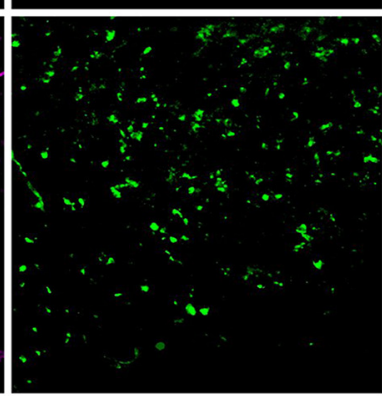

Hoechst: Nuclear Counterstain Olig2: Oligodendrocyte lineage cells CC1: Mature Oligodendrocytes

Figure 6. Creatine administration enhances oligodendrocyte restoration after focal spinal cord demyelination. $A, B$, Quantification of immunostaining for Nkx2.2 $2^{+}$Olig2 $2^{+}$OPCS per square millimeter $(\boldsymbol{A})$ and $\mathrm{CC}^{+}$Olig2 ${ }^{+}$oligodendrocytes per square millimeter $(\boldsymbol{B})$ at 5,10 , and $20 \mathrm{dpl}$ in mice treated with PBS or $25 \mathrm{ng}$ of creatine (CR). $n=3$ mice/condition; Student's $t$ test. C, Representative immunostaining of mature oligodendrocytes double positive for 0 lig2 (magenta) and CC1 (green) in PBS and CR lesions at 5dpl. Data are represented as mean \pm SEM. Scale bars, $100 \mu \mathrm{m}$. Brightness and contrast were adjusted for visualization. $n=3$ mice/condition; ${ }^{*} p<0.05,{ }^{* *} p<0.01,{ }^{* * *} p<0.001,{ }^{* * * *} p<0.0001$. 



E

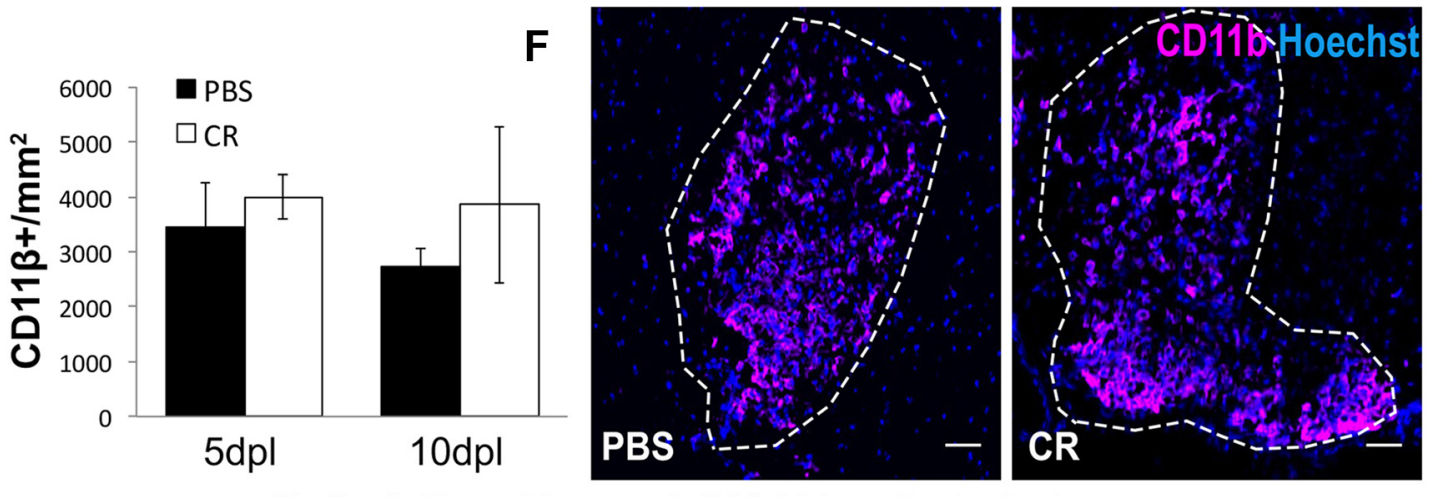

Clv-Csp3: Cleaved Caspase-3 CC1: Mature oligodendroytes

Hoechst: Nuclear counterstain MBP: Myelin basic protein CD11b: Macrophage/monocytes

Figure 7. Creatine administration enhances oligodendrocyte survival after focal spinal cord demyelination. $A$, Representative immunostainings of dying oligodendrocytes in mice treated with PBS or $25 \mathrm{ng}$ of creatine (CR) at $5 \mathrm{dpl}$. White arrows indicate cells double positive for Clv-Csp3 and CC1. Scale bars, $50 \mu \mathrm{m}$. B, Quantification of immunostaining showing the proportion of oligodendrocytes positive for cleaved caspase-3 $\left(\mathrm{Clv}-\mathrm{Csp}^{+}{ }^{+} \mathrm{CC}^{+}\right)$of total oligodendrocytes $\left(\mathrm{CC}^{+}\right)$in PBS and CR lesions at 5dpl. $n=2$ mice/condition; Student's $t$ test. $C$, Representative immunostainings of MBP in PBS-treated and creatine-treated (CR) lesions at $20 \mathrm{dpl}$. Scale bars, $100 \mu \mathrm{m}$. D, Quantification of immunostaining showing average MBP intensity per square micrometer in PBS and CR lesions at 20dpl. $n=3$ mice/condition; Student's $t$ test. $E$, Quantification of immunostaining for CD11 $\mathrm{b}^{+}$cells $/ \mathrm{mm}^{2}$ in PBS and CR lesions at 5 and $10 \mathrm{dpl} . n=3$ mice/condition; Student's $t$ test. $\boldsymbol{F}$, Representative immunostainings of macrophages/microglia (CD11b ${ }^{+}$; magenta) in PBS and CR lesions at $5 \mathrm{dpl}$. Data are represented as mean \pm SEM. Scale bars, $50 \mu \mathrm{m}$. Brightness and contrast were adjusted for visualization. ${ }^{*} p<0.05,{ }^{* *} p<0.01,{ }^{* * *} p<0.001,{ }^{* * *} p<0.0001$

cord lesions were conducted on 9- to 12-week-old wild-type and $\mathrm{Gamt}^{-1-}$ mice and lesions were identified by focal accumulation of Hoechst-positive nuclei, thought to represent an influx of inflammatory cells to the injury site. Gamt deficiency did not affect OPC $\left(\mathrm{Nkx} 2.2^{+} \mathrm{Olig}^{+}\right)$, oligodendrocyte $\left(\mathrm{OL} ; \mathrm{CC}^{+} \mathrm{Olig} 2^{+}\right)$, or total oligodendrocyte lineage cell (Lineage; Olig2 ${ }^{+}$) density in NAWM adjacent to lesions (Fig. 4A). Although Gamt deficiency had no effect on the recruitment of $\mathrm{Nkx} 2.2^{+} \mathrm{Olig} 2^{+}$OPCs to the lesions across all three time points examined (Fig. $4 B-D$ ), significantly fewer $\mathrm{CC}^{+}$Olig2 ${ }^{+}$oligodendrocytes were present in Gamt $^{-1-}$ lesions at $10 \mathrm{dpl}$ (Fig. 4C,E; $n=3$ mice/condition; $p=$ 0.003 ) and $20 \mathrm{dpl}$ (Fig. $4 D ; n=3$ mice/condition; $p=0.0185$ ), suggesting that Gamt deficiency impaired oligodendrocyte differentiation or reduced the survival of newly regenerated oligodendrocytes. Moreover, coinjection of $25 \mathrm{ng}$ of creatine with lysolecithin into $\mathrm{Gamt}^{-1-}$ animals at the time of surgery (GAMT-KO + creatine) led to significantly more $\mathrm{CC}^{+}{ }^{+}$Olig $2^{+}$ oligodendrocytes in the lesion at $10 \mathrm{dpl}$ compared with Gamt ${ }^{-1-}$ animals coinjected with PBS (Fig. $4 C, E ; n=3$ mice/condition; $p=0.008$ ), suggesting that creatine treatment is able to rescue oligodendrocyte density in Gamt-deficient lesions. The robust prosurvival effect of creatine in vitro (Figs. 2, 3) led us to hypothesize that the reduction of oligodendrocytes in Gamt ${ }^{-1-}$ lesions may be the result of impaired oligodendrocyte viability. To quantify oligodendrocyte cell death in lesions, coimmunostaining analysis for CC1 and cleaved caspase-3 (Clv-Csp3), a critical executioner protein involved in oligodendrocyte cell death (Casaccia-Bonnefil, 2000), was performed. Although the number of Clv-Csp $3^{+} \mathrm{CC}^{+}$oligodendrocytes was not different between groups at $5 \mathrm{dpl}$ (data not shown), it was significantly increased in 


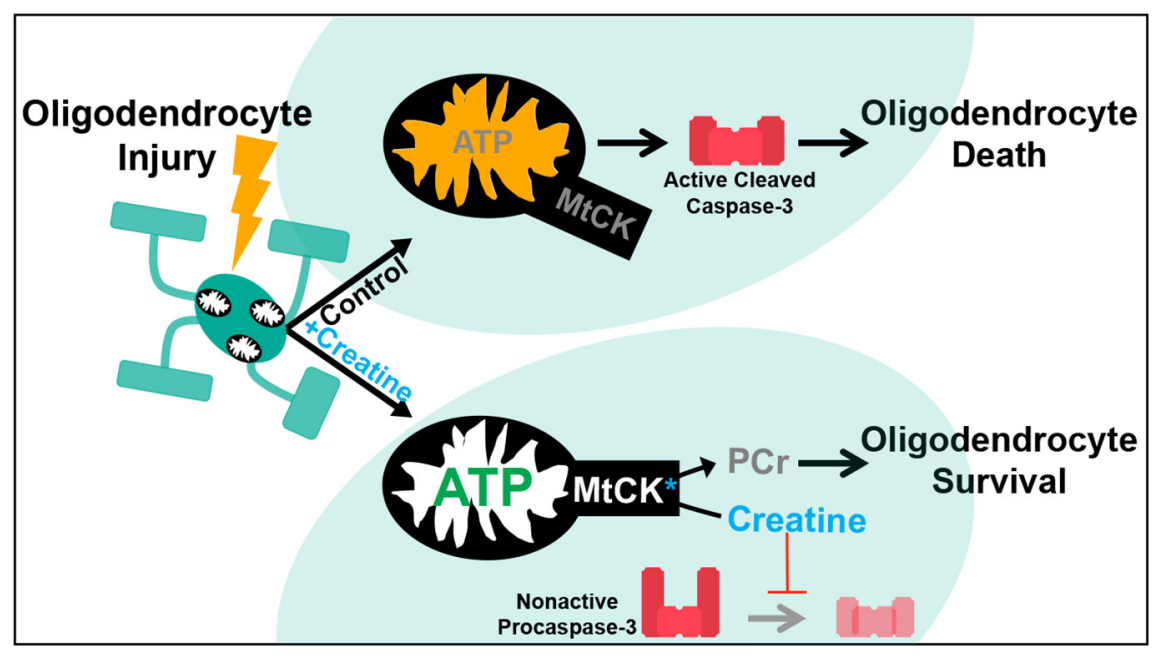

Figure 8. Hypothesized model for creatine-mediated protection of oligodendrocytes. Creatine treatment promotes oligodendrocyte restoration after demyelinating injury by inhibiting caspase-dependent oligodendrocyte death. Although the precise mechanism remains to be elucidated, it is hypothesized that creatine activation of MtCK may inhibit apoptotic initiation directly.

Gamt $^{-1-}$ lesions at $10 \mathrm{dpl}$ (Fig. $5 A-C ; n=3$ mice/condition; $p=$ $0.001)$. Compared to coinjection with PBS, coinjection with creatine reduced the number of $\mathrm{Clv}-\mathrm{Csp} 3{ }^{+} \mathrm{CC}^{+}$oligodendrocytes in $\mathrm{Gamt}^{-1-}$ lesions by $47 \%$ (Fig. $5 A, D ; n=3$ mice/condition; $p=0.004)$. Therefore, despite regenerating from OPCs, oligodendrocytes within Gamt-deficient lesions are unable to survive in the absence of creatine. To investigate whether changes in inflammation contributed to altered oligodendrocyte viability in lesions, we quantified the density of $\mathrm{CD} 11 \mathrm{~b}^{+}$macrophages/microglial cells at 5 and $10 \mathrm{dpl}$ and found no differences between wild-type and Gamt ${ }^{-1-}$ mice at 5 or $10 \mathrm{dpl}$ (Fig. 5E-G), suggesting that GAMT does not affect macrophage/microglia number in lesions and is required specifically for oligodendrocyte viability.

\section{Creatine administration increases oligodendrocyte density after focal spinal cord demyelination}

Creatine has proven safe and well tolerated in clinical trials (Malin et al., 2008; Rosenfeld et al., 2008), but its effect on oligodendrocyte survival in MS remains unknown. To determine whether exogenous creatine administration promotes oligodendrocyte survival in wild-type CNS lesions, spinal cords of WT mice were coinjected with lysolecithin and either PBS or $25 \mathrm{ng}$ of creatine. We found that creatine had no effect on the number of Nxk2.2 $2^{+}$Olig2 ${ }^{+}$OPCs at any of the postlesion time points examined (Fig. $6 A ; n=3$ mice/condition), but increased the density of $\mathrm{CC}^{+}$Olig2 ${ }^{+}$oligodendrocytes significantly at both 5 and $10 \mathrm{dpl}$ (Fig. $6 B, C ; n=3$ mice/condition; $p=0.0254, p=0.0022$ ). The observation that creatine-treated mice exhibited increased oligodendrocyte density suggests that creatine may promote the survival of oligodendrocytes within the lesion. Indeed, we observed that creatine-treated mice had significantly fewer Clv-Csp $3^{+}$oligodendrocytes at $5 \mathrm{dpl}$ compared with PBS-treated mice (Fig. $7 A, B ; n=3$ mice/condition; $p=0.0051$ ), demonstrating a role for creatine in the inhibition of caspase-dependent oligodendrocyte apoptosis. Moreover, we detected increased MBP staining in lesions at $20 \mathrm{dpl}$ in creatine-treated mice compared with control, suggesting that creatine-mediated oligodendrocyte survival enhanced CNS remyelination (Fig. $7 C, D ; n=3$ mice/condition; $p=0.0019)$. Because creatine did not affect the density of inflammatory macrophages/microglia at 5 or $10 \mathrm{dpl}$ (Fig. $7 E, F$ ), changes in inflammation are unlikely to mediate the beneficial effect of creatine. This result suggests that creatine administration can enhance oligodendrocyte survival directly in the CNS.

\section{Discussion}

The CNS uses $20 \%$ of the body's energy (Mergenthaler et al., 2013), with the human cortex alone requiring $\sim 3 \times 10^{23}$ $\mathrm{ATP} / \mathrm{s} / \mathrm{m}^{3}$ (Howarth et al., 2012). Creatine is thought to play a critical role in meeting this energy demand by allowing for rapid ATP regeneration in the cytoplasm (Wyss and Kaddurah-Daouk, 2000). Within the CNS, oligodendrocytes have a preferentially high capacity for creatine synthesis (Braissant et al., 2001; Tachikawa et al., 2004; Cahoy et al., 2008; Zhang et al., 2014), suggesting that they may be a major source of creatine in the brain. Therefore, we investigated the role of creatine in oligodendrocytes using both in vitro and in vivo approaches.

In purified oligodendrocyte lineage cells, creatine increased oligodendrocyte mitochondrial density, membrane potential, and ATP production directly. We found that enhanced mitochondrial function in creatine-treated oligodendrocytes did not increase membrane expansion or differentiation, but rather promoted oligodendrocyte survival. Creatine treatment of primary mixed glia cultures for $48 \mathrm{~h}$ reduced oligodendrocyte cell death significantly. Further, OPC proliferation was also reduced in creatine-treated cultures. Despite these underlying changes, no differences were observed in the overall proportions of OPCs and oligodendrocytes after either 24 or $48 \mathrm{~h}$ of treatment. Because we did not quantify $\mathrm{O}^{+} \mathrm{MBP}^{-}$preoligodendrocytes directly, we cannot rule out the possibility that creatine may have affected the proportion of this intermediate population. However, at the experimental end point, $\mathrm{O}^{+}$highly overlapped with $\mathrm{MBP}^{+}$in our cultures, making robust quantification of this population difficult. Inclusion of additional time points in the $24-48 \mathrm{~h}$ treatment window could address this question in future studies. The simultaneous changes in oligodendrocyte death and OPC proliferation suggest an active mechanism for maintaining homeostatic density of oligodendrocytes reminiscent to that recently described in vivo (Hughes et al., 2013).

In contrast, acute $(24 \mathrm{~h})$ LPS-mediated inflammatory injury altered the proportions of oligodendrocyte lineage cells significantly. LPS treatment reduced the proportion of oligodendrocytes and concomitantly increased oligodendrocyte apoptosis, both of which were returned to control levels by cotreatment with creatine. As reported previously, we found that OPCs exhibit both increased apoptosis and proliferation in response to LPS treatment (Li et al., 2008; Skripuletz et al., 2011). However, creatine did not affect either of these parameters significantly, indicating that changes in OPC proportion are a reflection of oligodendrocyte loss rather than a direct effect of creatine on OPCs. It is interesting that creatine did not reduce the level of oligodendrocyte apoptosis below PBS in this experiment. This effect may be due to the acute timing of LPS treatment ( $24 \mathrm{~h}$ ) rather than different underlying mechanisms of inflammatory and noninflammatory cell death in vitro because previous work suggests that oligodendrocytes undergo apoptosis both as a normal turnover response and as a result of cytokine- or glutamate- 
induced excitotoxicity in the presence of activated microglia (Barres et al., 1992; Matute et al., 2006; Aktas at al., 2006).

To determine whether creatine also affected oligodendrocyte survival in vivo, we conducted loss-of-function experiments by performing focal spinal cord demyelination on Gamt-deficient mice and quantifying the process of spontaneous oligodendrocyte regeneration. Lesions of Gamt-deficient mice contained fewer total oligodendrocytes and a higher proportion of cleaved caspase-3-positive oligodendrocytes compared with controls. Injection of creatine at the time of surgery rescued the detrimental effect of Gamt deficiency on oligodendrocyte apoptosis, suggesting that creatine is necessary for survival of newly generated oligodendrocytes. Oligodendrocyte lineage cell numbers were not different in the NAWM of Gamt-deficient mice, suggesting that survival of the oligodendrocyte lineage is either not affected during development or compensatory mechanisms allow for normalization of these densities over time.

Further supporting a role for creatine in the survival of newly generated oligodendrocytes, lesions treated with exogenous creatine at the time of injury contained more oligodendrocytes at 5 and $10 \mathrm{dpl}$ due to a reduction in caspase-mediated oligodendrocyte cell death. Interestingly, by $20 \mathrm{dpl}$, PBS-treated lesions contain similar numbers of oligodendrocytes as those treated with creatine. Therefore, it appears that creatine serves to promote oligodendrocyte survival early in the injury time course, when inflammation remains high. Creatine treatment was also associated with elevated MBP expression, suggesting that creatine may enhance myelin synthesis or speed up the spontaneous process of myelin regeneration in vivo. Addition of exogenous creatine or loss of Gamt did not affect the recruitment of inflammatory cells, suggesting that creatine promotes oligodendrocyte viability directly.

Despite the high expression of creatine-synthesizing enzymes in oligodendrocytes (Tachikawa et al., 2004; Braissant et al., 2010; Takasaki et al., 2010; Zhang et al., 2014), its physiological importance in these cells had not been investigated. Our results suggest a model in which creatine promotes the viability of newly generated oligodendrocytes by enhancing mitochondrial function (Fig. 8). Several mechanisms of creatine-mediated protection have been proposed. Creatine can serve as a direct antioxidant (Lawler et al., 2002) and reduces markers of oxidative stress in rodent models of neurological insult (Hosamani et al., 2010; Saraiva et al., 2012; Cunha et al., 2013; Rambo et al., 2013). Creatine also inhibits loss of mitochondrial membrane potential (Rambo et al., 2013), which has been shown to precede initiation of cellular apoptosis (Kroemer et al., 2007). In addition, creatine activation of MtCK directly inhibits the opening of the mitochondrial permeability transition pore, an early apoptotic event concomitant with cytochrome-c release (Beutner et al., 1996; O'Gorman et al., 1997; Beutner et al., 1998; Vyssokikh and Brdiczka, 2003; Schlattner et al., 2006). Our loss- and gain-of-function studies yielded complementary results, demonstrating that creatine increases oligodendrocyte density during CNS regeneration by inhibiting caspase-dependent cell death of mature oligodendrocytes. Although caspase- 3 can be activated by both intrinsic (mitochondrial) and extrinsic (death receptor) pathways, our finding that creatine increases mitochondrial membrane potential and ATP production directly in oligodendrocyte lineage cells suggests that creatine protection is mediated by a mitochondrialdependent mechanism. Future studies are necessary to address whether creatine activation of MtCK promotes oligodendrocyte viability.

Oligodendrocyte death plays a crucial role in the pathology of MS (Matute et al., 2006; Macchi et al., 2015). In demyelinated lesions, oligodendrocyte death may be achieved with or without complement activation (Lucchinetti et al., 2000; Barnett and Prineas, 2004). Moreover, oligodendrocytes can undergo either apoptosis or necrosis, depending on how mitochondrial function is affected (Casaccia-Bonnefil, 2000). Many oligodendrocytes appear to survive demyelination in chronic-stage MS, but are lost from lesioned areas gradually over time (Wolswijk, 2000), suggesting that their survival may be compromised under chronic inflammation. Preventing oligodendrocyte cell death in MS is particularly important considering that current therapies do not prevent transition into secondary-progressive disease (Huang and Franklin, 2012), in which chronic demyelination is thought to contribute to neurodegeneration (Jeffery and Blakemore, 1997; Kornek et al., 2000; Irvine and Blakemore, 2008). In addition, the past few decades have demonstrated novel roles for oligodendrocytes in maintaining neuronal health and integrity (Nave and Trapp, 2008; Fünfschilling et al., 2012; Lee et al., 2012), underscoring the importance of maintaining the oligodendrocyteaxon connection. Our work demonstrates that creatine promotes survival of oligodendrocytes under inflammatory conditions both in vitro and in vivo. It is therefore exciting to consider creatine as a potential treatment strategy for protecting oligodendrocytes in patients with MS. Dietary creatine supplementation has proven safe and well tolerated in clinical trials (Kahler and Fahey, 2003). It has also been demonstrated to improve brain performance (Rae et al., 2003) and protect neurons during oxygen deprivation (Turner et al., 2015). Therefore, future work is needed to elucidate whether dietary creatine supplementation or the administration of creatine analogs can protect oligodendrocytes in both the laboratory and clinical setting.

In summary, we have found a novel role for creatine in promoting oligodendrocyte viability. Our results suggest that creatine may be a potentially relevant therapeutic agent for promoting oligodendrocyte survival in MS.

\section{References}

Akassoglou K, Bauer J, Kassiotis G, Pasparakis M, Lassmann H, Kollias G, Probert L (1998) Oligodendrocyte apoptosis and primary demyelination induced by local TNF/p55TNF receptor signaling in the central nervous system of transgenic mice: models for multiple sclerosis with primary oligodendrogliopathy. Am J Pathol 153:801-813. CrossRef Medline

Aktas O, Prozorovski T, Zipp F (2006) Death ligands and autoimmune demyelination. Neuroscientist 12:305-316. CrossRef Medline

Andres RH, Ducray AD, Huber AW, Pérez-Bouza A, Krebs SH, Schlattner U, Seiler RW, Wallimann T, Widmer HR (2005) Effects of creatine treatment on survival and differentiation of GABA-ergic neurons in cultured striatal tissue. J Neurochem 95:33-45. CrossRef Medline

Anselm IA, Alkuraya FS, Salomons GS, Jakobs C, Fulton AB, Mazumdar M, Rivkin M, Frye R, Poussaint TY, Marsden D (2006) X-linked creatine transporter defect: a report on two unrelated boys with a severe clinical phenotype. J Inherit Metab Dis 29:214-219. CrossRef Medline

Arnett HA, Fancy SP, Alberta JA, Zhao C, Plant SR, Kaing S, Raine CS, Rowitch DH, Franklin RJ, Stiles CD (2004) bHLH transcription factor Olig1 is required to repair demyelinated lesions in the CNS. Science 306: 2111-2115. CrossRef Medline

Baerwald KD, Popko B (1998) Developing and mature oligodendrocytes respond differently to the immune cytokine interferon-gamma. J Neurosci Res 52:230-239. Medline

Barkovich AJ (2011) Pediatric neuroimaging. 5th Ed. Philadelphia, PA: LWW.

Barnett MH, Prineas JW (2004) Relapsing and remitting multiple sclerosis: pathology of the newly forming lesion. Ann Neurol 55:458-468. CrossRef Medline

Barres BA, Hart IK, Coles HS, Burne JF, Voyvodic JT, Richardson WD, Raff MC (1992) Cell death and control of cell survival in the oligodendrocyte lineage. Cell 70:31-46. 
Behar TN (2001) Analysis of fractal dimension of O2A glial cells differentiating in vitro. Methods 24:331-339. CrossRef Medline

Berti SL, Nasi GM, Garcia C, Castro FL, Nunes ML, Rojas DB, Moraes TB, Dutra-Filho CS, Wannmacher CM (2012) Pyruvate and creatine prevent oxidative stress and behavioral alterations caused by phenylalanine administration into hippocampus of rats. Metab Brain Dis 27:79-89. CrossRef Medline

Beutner G, Ruck A, Riede B, Welte W, Brdiczka D (1996) Complexes between kinases, mitochondrial porin and adenylate translocator in rat brain resemble the permeability transition pore. FEBS Lett 396(2-3):189-195.

Beutner G, Rück A, Riede B, Brdiczka D (1998) Complexes between porin, hexokinase, mitochondrial creatine kinase and adenylate translocator display properties of the permeability transition pore: implication for regulation of permeability transition by the kinases. Biochim Biophys Acta 1368:7-18. CrossRef Medline

Bieber AJ, Kerr S, Rodriguez M (2003) Efficient central nervous system remyelination requires T cells. Ann Neurol 53:680-684. CrossRef Medline

Braissant O, Henry H, Loup M, Eilers B, Bachmann C (2001) Endogenous synthesis and transport of creatine in the rat brain: an in situ hybridization study. Brain Res Mol Brain Res 86(1-2):193-201.

Braissant O, Béard E, Torrent C, Henry H (2010) Dissociation of AGAT, GAMT and SLC6A8 in CNS: relevance to creatine deficiency syndromes. Neurobiol Dis 37:423-433. CrossRef Medline

Cahoy JD, Emery B, Kaushal A, Foo LC, Zamanian JL, Christopherson KS, Xing Y, Lubischer JL, Krieg PA, Krupenko SA, Thompson WJ, Barres BA (2008) A transcriptome database for astrocytes, neurons, and oligodendrocytes: a new resource for understanding brain development and function. J Neurosci 28:264-278. CrossRef Medline

Casaccia-Bonnefil P (2000) Cell death in the oligodendrocyte lineage: a molecular perspective of life / death decisions in development and disease. Glia 29:124-135. Medline

Compston A, Coles A (2008) Multiple sclerosis. Lancet 372:1502-1517. CrossRef Medline

Cunha MP, Martín-de-Saavedra MD, Romero A, Parada E, Egea J, Del Barrio L, Rodrigues AL, López MG (2013) Protective effect of creatine against 6-hydroxydopamine-induced cell death in human neuroblastoma SHSY5Y cells: Involvement of intracellular signaling pathways. Neuroscience 238:185-194. CrossRef Medline

Daniele SG, Edwards AA, Maguire-Zeiss KA (2014) Isolation of cortical microglia with preserved immunophenotype and functionality from murine neonates. J Vis Exp 83:e51005. CrossRef Medline

Dincman TA, Beare JE, Ohri SS, Whittemore SR (2012) Isolation of cortical mouse oligodendrocyte precursor cells. J Neurosci Methods 209:219226. CrossRef Medline

Dutta R, Trapp BD (2011) Mechanisms of neuronal dysfunction and degeneration in multiple sclerosis. Prog Neurobiol 93:1-12. CrossRef Medline

Fitzner D, Simons M (2010) Chronic progressive multiple sclerosis: pathogenesis of neurodegeneration and therapeutic strategies. Curr Neuropharmacol 8:305-315. CrossRef Medline

Franklin RJ (2002) Why does remyelination fail in multiple sclerosis? Nat Rev Neurosci 3:705-714. CrossRef Medline

Franklin RJ, Gallo V (2014) The translational biology of remyelination: past, present, and future. Glia 62:1905-1915. CrossRef Medline

Fünfschilling U, Supplie LM, Mahad D, Boretius S, Saab AS, Edgar J, Brinkmann BG, Kassmann CM, Tzvetanova ID, Möbius W, Diaz F, Meijer D, Suter U, Hamprecht B, Sereda MW, Moraes CT, Frahm J, Goebbels S, Nave KA (2012) Glycolytic oligodendrocytes maintain myelin and longterm axonal integrity. Nature 485:517-521. CrossRef Medline

Haines JD, Inglese M, Casaccia P (2011) Axonal damage in multiple sclerosis. Mt Sinai J Med 78:231-243. CrossRef Medline

Harris JJ, Attwell D (2012) The energetics of CNS white matter.J Neurosci 32:356-371. CrossRef

Hisahara S, Araki T, Sugiyama F, Yagami Ki, Suzuki M, Abe K, Yamamura K, Miyazaki J, Momoi T, Saruta T, Bernard CC, Okano H, Miura M (2000) Targeted expression of baculovirus p35 caspase inhibitor in oligodendrocytes protects mice against autoimmune-mediated demyelination. EMBO J 19:341-348. CrossRef Medline

Hosamani R, Ramesh SR, Muralidhara (2010) Attenuation of rotenoneinduced mitochondrial oxidative damage and neurotoxicity in Drosophila melanogaster supplemented with creatine. Neurochem Res 35:1402-1412. CrossRef Medline
Howarth C, Gleeson P, Attwell D (2012) Updated energy budgets for neural computation in the neocortex and cerebellum. J Cereb Blood Flow Metab 32:1222-1232 CrossRef Medline

Huang JK, Jarjour AA, Nait Oumesmar B, Kerninon C, Williams A, Krezel W, Kagechika H, Bauer J, Zhao C, Baron-Van Evercooren A, Chambon P, Ffrench-Constant C, Franklin RJ (2011) Retinoid X receptor gamma signaling accelerates CNS remyelination. Nat Neurosci 14:45-53. CrossRef Medline

Huang JK, Franklin RJ (2012) Current status of myelin replacement therapies in multiple sclerosis. Prog Brain Res 201:219-231. CrossRef Medline

Hughes EG, Kang SH, Fukaya M, Bergles DE (2013) Oligodendrocyte progenitors balance growth with self-repulsion to achieve homeostasis in the adult brain. Nat Neurosci 16:668-676. CrossRef Medline

Irvine KA, Blakemore WF (2008) Remyelination protects axons from demyelination-associated axon degeneration. Brain 131:1464-1477. CrossRef Medline

Jablonska B, Scafidi J, Aguirre A, Vaccarino F, Nguyen V, Borok E, Horvath TL, Rowitch DH, Gallo V (2012) Oligodendrocyte regeneration after neonatal hypoxia requires FoxO1-mediated p27Kip1 expression. J Neurosci 32:14775-14793. CrossRef Medline

Jeffery ND, Blakemore WF (1997) Locomotor deficits induced by experimental spinal cord demyelination are abolished by spontaneous remyelination. Brain 120:27-37. CrossRef Medline

Kahler SG, Fahey MC (2003) Metabolic disorders and mental retardation. Am J Med Genet C Semin Med Genet 117C:31-41. CrossRef Medline

Klivenyi P, Ferrante RJ, Matthews RT, Bogdanov MB, Klein AM, Andreassen OA, Mueller G, Wermer M, Kaddurah-Daouk R, Beal MF (1999) Neuroprotective effects of creatine in a transgenic animal model of amyotrophic lateral sclerosis. Nat Med 5:347-350. CrossRef Medline

Kornek B, Storch MK, Weissert R, Wallstroem E, Stefferl A, Olsson T, Linington C, Schmidbauer M, Lassmann H (2000) Multiple sclerosis and chronic autoimmune encephalomyelitis: a comparative quantitative study of axonal injury in active, inactive, and remyelinated lesions. Am J Pathol 157:267-276. CrossRef Medline

Kroemer G, Galluzzi L, Brenner C (2007) Mitochondrial membrane permeabilization in cell death. Physiol Rev 87:99-163. CrossRef Medline

Lassmann H (2016) Demyelination and neurodegeneration in multiple sclerosis: the role of hypoxia. Ann Neurol 79:520-521. CrossRef Medline

Lawler JM, Barnes WS, Wu G, Song W, Demaree S (2002) Direct antioxidant properties of creatine. Biochem Biophys Res Commun 290:47-52. CrossRef Medline

Lee CW, Peng HB (2008) The function of mitochondria in presynaptic development at the neuromuscular junction. Mol Biol Cell 19:150-158. CrossRef Medline

Lee Y, Morrison BM, Li Y, Lengacher S, Farah MH, Hoffman PN, Liu Y, Tsingalia A, Jin L, Zhang PW, Pellerin L, Magistretti PJ, Rothstein JD (2012) Oligodendroglia metabolically support axons and contribute to neurodegeneration. Nature 487:443-448 CrossRef Medline

Lin W, Bailey SL, Ho H, Harding HP, Ron D, Miller SD, Popko B (2007) The integrated stress response prevents demyelination by protecting oligodendrocytes against immune-mediated damage. J Clin Invest 117:448456. CrossRef Medline

Li Z, Okamoto K, Hayashi Y, Sheng M (2004) The importance of dendritic mitochondria in the morphogenesis and plasticity of spines and synapses. Cell 119:873-887. CrossRef Medline

Li J, Baud O, Vartanian T, Volpe JJ, Rosenberg PA (2005) Peroxynitrite generated by inducible nitric oxide synthase and NADPH oxidase mediates microglial toxicity to oligodendrocytes. Proc Natl Acad Sci U S A 102:9936-9941. CrossRef Medline

Li J, Ramenaden ER, Peng J, Koito H, Volpe JJ, Rosenberg PA (2008) Tumor necrosis factor alpha mediates lipopolysaccharide-induced microglial toxicity to developing oligodendrocytes when astrocytes are present. J Neurosci 28:5321-5330. CrossRef Medline

Lucchinetti C, Brück W, Parisi J, Scheithauer B, Rodriguez M, Lassmann H (2000) Heterogeneity of multiple sclerosis lesions: implications for the pathogenesis of demyelination. Ann Neurol 47:707-717. CrossRef Medline

Macchi B, Marino-Merlo F, Nocentini U, Pisani V, Cuzzocrea S, Grelli S, Mastino A (2015) Role of inflammation and apoptosis in multiple sclerosis: comparative analysis between the periphery and the central nervous system. J Neuroimmunol 287:80-87. CrossRef Medline

Malin SK, Cotugna N, Fang CS (2008) Effect of creatine supplementation 
on muscle capacity in individuals with multiple sclerosis. J Diet Suppl 5:20-32. CrossRef Medline

Manos P, Bryan GK, Edmond J (1991) Creatine kinase activity in postnatal rat brain development and in cultured neurons, astrocytes, and oligodendrocytes. J Neurochem 56:2101-2107. CrossRef Medline

Matthews RT, Yang L, Jenkins BG, Ferrante RJ, Rosen BR, Kaddurah-Daouk R, Beal MF (1998) Neuroprotective effects of creatine and cyclocreatine in animal models of Huntington's disease. J Neurosci 18:156-163. Medline

Matthews RT, Ferrante RJ, Klivenyi P, Yang L, Klein AM, Mueller G, Kaddurah-Daouk R, Beal MF (1999) Creatine and cyclocreatine attenuate MPTP neurotoxicity. Exp Neurol 157:142-149. CrossRef Medline

Matute C, Domercq M, Sánchez-Gómez MV (2006) Glutamate-mediated glial injury: mechanisms and clinical importance. Glia 53:212-224. CrossRef Medline

Mc Guire C, Volckaert T, Wolke U, Sze M, de Rycke R, Waisman A, Prinz M, Beyaert R, Pasparakis M, van Loo G (2010) Oligodendrocyte-specific FADD deletion protects mice from autoimmune-mediated demyelination. J Immunol 185:7646-7653. CrossRef Medline

McIver SR, Muccigrosso M, Gonzales ER, Lee JM, Roberts MS, Sands MS, Goldberg MP (2010) Oligodendrocyte degeneration and recovery after focal cerebral ischemia. Neuroscience 169:1364-1375. CrossRef Medline

Mergenthaler P, Lindauer U, Dienel GA, Meisel A (2013) Sugar for the brain: the role of glucose in physiological and pathological brain function. Trends Neurosci 36:587-597. CrossRef Medline

Molloy GR, Wilson CD, Benfield P, de Vellis J, Kumar S (1992) Rat brain creatine kinase messenger RNA levels are high in primary cultures of brain astrocytes and oligodendrocytes and low in neurons. J Neurochem 59:1925-1932. CrossRef Medline

Morris RL, Hollenbeck PJ (1993) The regulation of bidirectional mitochondrial transport is coordinated with axonal outgrowth. J Cell Sci 104:917927. Medline

Nave KA, Trapp BD (2008) Axon-glial signaling and the glial support of axon function. Annu Rev Neurosci 31:535-561. CrossRef Medline

Ness JK, Romanko MJ, Rothstein RP, Wood TL, Levison SW (2001) Perinatal hypoxia-ischemia induces apoptotic and excitotoxic death of periventricular white matter oligodendrocyte progenitors. Dev Neurosci 23:203-208. CrossRef Medline

O'Gorman E, Beutner G, Dolder M, Koretsky AP, Brdiczka D, Wallimann T (1997) The role of creatine kinase in inhibition of mitochondrial permeability transition. FEBS Lett 414:253-257. CrossRef Medline

Pavelko KD, van Engelen BG, Rodriguez M (1998) Acceleration in the rate of CNS remyelination in lysolecithin-induced demyelination. J Neurosci 18:2498-2505. Medline

Perry SW, Norman JP, Barbieri J, Brown EB, Gelbard HA (2011) Mitochondrial membrane potential probes and the proton gradient: a practical usage guide. Biotechniques 50:98-115. CrossRef Medline

Rae C, Digney AL, McEwan SR, Bates TC (2003) Oral creatine monohydrate supplementation improves brain performance: a double-blind, placebo-controlled, cross-over trial. Proc Biol Sci 270:2147-2150. CrossRef Medline

Rambo LM, Ribeiro LR, Della-Pace ID, Stamm DN, da Rosa Gerbatin R, Prigol M, Pinton S, Nogueira CW, Furian AF, Oliveira MS, Fighera MR, Royes LF (2013) Acute creatine administration improves mitochondrial membrane potential and protects against pentylenetetrazol-induced seizures. Amino Acids 44:857-868. CrossRef Medline

Rice CM (2014) Disease modification in multiple sclerosis: an update. Pract Neurol 14:6-13. CrossRef Medline

Richter-Landsberg C, Heinrich M (1996) OLN-93: a new permanent oligodendroglia cell line derived from primary rat brain glial cultures. J Neurosci Res 45:161-173. Medline

Rosenfeld J, King RM, Jackson CE, Bedlack RS, Barohn RJ, Dick A, Phillips LH, Chapin J, Gelinas DF, Lou JS (2008) Creatine monohydrate in ALS: effects on strength, fatigue, respiratory status and ALSFRS. Amyotroph Lateral Scler 9:266-272. CrossRef Medline

Saraiva AL, Ferreira AP, Silva LF, Hoffmann MS, Dutra FD, Furian AF, Ol- iveira MS, Fighera MR, Royes LF (2012) Creatine reduces oxidative stress markers but does not protect against seizure susceptibility after severe traumatic brain injury. Brain Res Bull 87(2-3):180-186.

Schlattner U, Tokarska-Schlattner M, Wallimann T (2006) Mitochondrial creatine kinase in human health and disease. Biochim Biophys Acta 1762: 164-180. CrossRef Medline

Schmidt A, Marescau B, Boehm EA, Renema WK, Peco R, Das A, Steinfeld R, Chan S, Wallis J, Davidoff M, Ullrich K, Waldschütz R, Heerschap A, De Deyn PP, Neubauer S, Isbrandt D (2004) Severely altered guanidino compound levels, disturbed body weight homeostasis and impaired fertility in a mouse model of guanidinoacetate N-methyltransferase (GAMT) deficiency. Hum Mol Genet 13:905-921. CrossRef Medline

Sestili P, Martinelli C, Bravi G, Piccoli G, Curci R, Battistelli M, Falcieri E, Agostini D, Gioacchini AM, Stocchi V (2006) Creatine supplementation affords cytoprotection in oxidatively injured cultured mammalian cells via direct antioxidant activity. Free Radic Biol Med 40:837-849. CrossRef Medline

Skripuletz T, Miller E, Grote L, Gudi V, Pul R, Voss E, Skuljec J, MoharreghKhiabani D, Trebst C, Stangel M (2011) Lipopolysaccharide delays demyelination and promotes oligodendrocyte precursor proliferation in the central nervous system. Brain Behav Immun 25:1592-1606. CrossRef Medline

Tachikawa M, Fukaya M, Terasaki T, Ohtsuki S, Watanabe M (2004) Distinct cellular expressions of creatine synthetic enzyme GAMT and creatine kinases uCK-Mi and CK-B suggest a novel neuron-glial relationship for brain energy homeostasis. Eur J Neurosci 20:144-160. CrossRef Medline

Takasaki C, Yamasaki M, Uchigashima M, Konno K, Yanagawa Y, Watanabe M (2010) Cytochemical and cytological properties of perineuronal oligodendrocytes in the mouse cortex. Eur J Neurosci 32:1326-1336. CrossRef Medline

Torremans A, Marescau B, Possemiers I, Van Dam D, D’Hooge R, Isbrandt D, De Deyn PP (2005) Biochemical and behavioural phenotyping of a mouse model for GAMT deficiency. J Neurol Sci 231(1-2):49-55.

Turner CE, Byblow WD, Gant N (2015) Creatine supplementation enhances corticomotor excitability and cognitive performance during oxygen deprivation. J Neurosci 35:1773-1780. CrossRef Medline

Vartanian T, Li Y, Zhao M, Stefansson K (1995) Interferon-gammainduced oligodendrocyte cell death: implications for the pathogenesis of multiple sclerosis. Mol Med 1:732-743. Medline

Vyssokikh MY, Brdiczka D (2003) The function of complexes between the outer mitochondrial membrane pore (VDAC) and the adenine nucleotide translocase in regulation of energy metabolism and apoptosis. Acta Biochim Pol 50:389-404. Medline

Walsh B, Tonkonogi M, Söderlund K, Hultman E, Saks V, Sahlin K (2001) The role of phosphorylcreatine and creatine in the regulation of mitochondrial respiration in human skeletal muscle. J Physiol 537:971-978. CrossRef Medline

Way SW, Podojil JR, Clayton BL, Zaremba A, Collins TL, Kunjamma RB, Robinson AP, Brugarolas P, Miller RH, Miller SD, Popko B (2015) Pharmaceutical integrated stress response enhancement protects oligodendrocytes and provides a potential multiple sclerosis therapeutic. Nat Commun 6:6532. CrossRef Medline

Wolswijk G (1998) Chronic stage multiple sclerosis lesions contain a relatively quiescent population of oligodendrocyte precursor cells. J Neurosci 18:601-609. Medline

Wolswijk G (2000) Oligodendrocyte survival, loss and birth in lesions of chronic-stage multiple sclerosis. Brain 123:105-115. CrossRef Medline

Wyss M, Kaddurah-Daouk R (2000) Creatine and creatinine metabolism. Physiol Rev 80:1107-1213. Medline

Zhang Y, Chen K, Sloan SA, Bennett ML, Scholze AR, O'Keeffe S, Phatnani HP, Guarnieri P, Caneda C, Ruderisch N, Deng S, Liddelow SA, Zhang C, Daneman R, Maniatis T, Barres BA, Wu JQ (2014) An RNA-sequencing transcriptome and splicing database of glia neurons, and vascular cells of the cerebral cortex. J Neurosci 34:11929-11947. CrossRef Medline 